\title{
Chemosynthesis influences food web and community structure in high-Arctic benthos
}

\author{
Emmelie K. L. Åström ${ }^{1,2, *}$, Michael L. Carroll ${ }^{1,3}$, Arunima Sen ${ }^{1,9}$, \\ Helge Niemann ${ }^{1,4,5,6}$, William G. Ambrose Jr. ${ }^{3,7}$, Moritz F. Lehmann ${ }^{4}$, JoLynn Carroll ${ }^{3,8}$ \\ ${ }^{1}$ CAGE-Centre for Arctic Gas hydrate, Environment and Climate, Department of Geosciences, \\ UiT-The Arctic University of Norway, 9037 Tromsø, Norway \\ ${ }^{2}$ Department of Arctic and Marine Biology, UiT-The Arctic University of Norway, 9037 Tromsø, Norway \\ ${ }^{3}$ Akvaplan-niva, FRAM-High North Research Centre for Climate and the Environment, 9296 Tromsø, Norway \\ ${ }^{4}$ Department of Environmental Sciences, University of Basel, Basel 4056, Switzerland \\ ${ }^{5}$ NIOZ-Royal Netherlands Institute for Sea Research, Department of Marine Microbiology and Biogeochemistry, \\ and Utrecht University, 1790 AB Den Burg, Texel, The Netherlands \\ ${ }^{6}$ Department of Earth Sciences, Faculty of Geosciences, Utrecht University, 3508 TC Utrecht, the Netherlands \\ ${ }^{7}$ School of the Coastal Environment, Coastal Carolina University, Conway, South Carolina 29528, USA \\ ${ }^{8}$ Department of Geosciences, UiT-The Arctic University of Norway, 9037 Tromsø, Norway \\ ${ }^{9}$ Present address: Faculty of Bioscience and Aquaculture, Nord University, 8049 Bodø, Norway
}

\begin{abstract}
Cold seeps are locations where seafloor communities are influenced by the seepage of methane and other reduced compounds from the seabed. We examined macro-infaunal benthos through community analysis and trophic structure using stable isotope analysis at 3 seep locations in the Barents Sea. These seeps were characterized by high densities of the chemosymbiotic polychaetes Siboglinidae, clade Frenulata (up to 32120 ind. $\mathrm{m}^{-2}$ ), and thyasirid bivalves, Mendicula cf. pygmaea (up to 4770 ind. $\mathrm{m}^{-2}$ ). We detected low $\delta^{13} \mathrm{C}$ signatures in chemosymbiotic polychaetes and in 3 species of omnivorous/predatory polychaetes. These $\delta^{13} \mathrm{C}$ signatures indicate the input of chemosynthesis-based carbon (CBC) into the food web. Applying a 2-source mixing model, we demonstrated that $28-41 \%$ of the nutrition of non-chemosymbiotic polychaetes originates from $\mathrm{CBC}$. We also documented large community variations and small-scale variability within and among the investigated seeps, showing that the impact of seepage on faunal community structure transcends geographic boundaries within the Barents Sea. Moreover, aggregations of heterotrophic macro- and megafauna associated with characteristic seep features (microbial mats, carbonate outcrops, and chemosymbiotic worm-tufts) add 3-dimensional structure and habitat complexity to the seafloor. Cold seeps contribute to the hydrocarbon-derived chemoautotrophy component of these ecosystems and to habitat complexity. These characteristics make the cold seeps of potential high ecological relevance in the functioning of the larger Arctic-Barents Sea ecosystem.
\end{abstract}

KEY WORDS: Cold seeps $\cdot$ Benthos $\cdot$ Methane $\cdot$ Trophic structure $\cdot$ Stable isotopes $\cdot$ Barents Sea Svalbard

\section{INTRODUCTION}

Offshore marine primary production originates largely from phytoplankton in surface waters (Syvertsen 1991, Søreide et al. 2006). In the Arctic, primary

${ }^{*}$ Corresponding author: emmelie.k.astrom@uit.no production is strongly linked to seasonal cycles and is constrained by an intense growth period of short duration during Arctic spring and summer (Wassmann et al. 2006). In addition to phytoplankton production, sea-ice algae can be an important marine photosyn-

() The authors 2019. Open Access under Creative Commons by Attribution Licence. Use, distribution and reproduction are unrestricted. Authors and original publication must be credited. 
thetic carbon source early in the spring (Syvertsen 1991, Hobson et al. 1995, Søreide et al. 2006). For benthos and other organisms below the photic zone, these communities are to a large extent reliant on the export of surface-water primary production and partially degraded organic matter to the seabed i.e. pelagicbenthic coupling (Graf 1989, Hobson et al. 1995, Renaud et al. 2008). In deep-sea systems, in situ dark inorganic carbon fixation via prokaryotes is also a significant carbon source supporting benthic communities (Sweetman et al. 2019). In the Arctic, the largescale seasonal variations, sea-ice cover, and ice-algae production in combination with sedimentation rates and grazing pressure by zooplankton may create a particularly strong cryo-pelagic-benthic coupling that regulates the composition and function of seafloor shelf-communities (Syvertsen 1991, Hobson et al. 1995, Wassmann et al. 2006). This conventional paradigm of offshore marine productivity is based on carbon originating mainly from photosynthesis via biosynthesis in ocean surface waters. At cold seeps, where hydrocarbons such as methane emanate from the seafloor, chemosynthesis is an alternative mode of carbon fixation (Brooks et al. 1987, Knittel \& Boetius 2009, Zapata-Hernández et al. 2014).

At the base of cold seep-associated food webs are specialized microbes that exploit methane and sulfide within anoxic sediments or within the tissues of various organisms (Dubilier et al. 2008, Knittel \& Boetius 2009, Levin et al. 2016). Among the most important are consortia of methanotrophic archaea and sulfate-reducing bacteria that mediate the anaerobic oxidation of methane (AOM) coupled to the reduction of sulfate. Free-living sulfur-oxidizing (= thiotrophic) bacteria (SOB) can in turn utilize the AOM end-product (sulfide) as an energy source for carbon fixation, and mutualistic associations (i.e. symbioses) occur between animals and aerobic methanotrophs and/or thiotrophic microbes. Energy is also indirectly channeled into, and through, the seep food web via trophic predator-prey interactions and microbial grazing (Decker \& Olu 2012, Niemann et al. 2013, Zapata-Hernández et al. 2014). Such symbiotic relationships and trophic interactions can result in habitats consisting of specialized faunal communities including typical chemosymbiotic cold seep fauna (e.g. bathymodiolin mussels, vesicomyid bivalves, and siboglinid tubeworms) (Bergquist et al. 2005, Vanreusel et al. 2009, Levin et al. 2016).

The importance of chemosynthetic carbon (CBC) in benthic food webs has been documented for cold seeps globally (Levin 2005, Decker \& Olu 2012, Zapata-Hernández et al. 2014). Stable isotope analysis has provided valuable insight into trophic interactions and the utilization of different carbon sources (Brooks et al. 1987, Ferrier-Pagès \& Leal 2018). By combining analyses of stable carbon $\left(\delta^{13} \mathrm{C}\right)$ and nitrogen $\left(\delta^{15} \mathrm{~N}\right)$ isotope ratios to assess energy sources and trophic structure, it is possible to investigate community characteristics and predator-prey interactions and to generate insights into resource utilization (Brooks et al. 1987, Hobson \& Welch 1992, Vander Zanden et al. 1999). Chemosynthetically fixed carbon can have either a ${ }^{13} \mathrm{C}$-enriched $\left(\delta^{13} \mathrm{C}\right.$ of -9 to $-16 \%$ ) or depleted $\left(\delta^{13} \mathrm{C}<-35 \%\right)$ carbon isotopic signature when compared to photosynthetically fixed carbon (House et al. 2003, Ferrie-Pagès \& Leal 2018). The lower (i.e. more negative) $\delta^{13} \mathrm{C}$ values within this bimodal spectrum for $\mathrm{CBC}$ can be attributed to the use of the enzyme Rubisco I as catalyst in the carbon fixation step of the Calvin Benson-Bassham cycle (CBB) (Robinson \& Cavanaugh 1995, Ferrier-Pagès \& Leal 2018). The higher (i.e. less negative) $\delta^{13} \mathrm{C}$ signatures can involve the $\mathrm{Ru}$ bisco II enzyme in the CBB cycle or the reductive tricarboxylic acid cycle (rTCA) for carbon fixation (Hügler \& Sievert 2011, Thiel et al. 2012). Methanotrophy can result in even lower $\delta^{13} \mathrm{C}$ signatures than those associated with carbon fixation via $\mathrm{CBB}$, and the degree of the ${ }^{13} \mathrm{C}$ depletion will depend on whether the source of methane is either thermogenic $\left(\delta^{13} \mathrm{C}\right.$ usually ranging from -37 to $-55 \%$ ) or microbial $\left(\delta^{13} \mathrm{C} \approx-60\right.$ to $-80 \%$ ) (Brooks et al. 1987, Martens et al. 1991, Holler et al. 2009). Finally, low $\delta^{13} \mathrm{C}$-biomass isotopic signatures may also arise from sequential fractionation, for example, when autotrophic sulfur oxidizers utilize ${ }^{13} \mathrm{C}$-depleted $\mathrm{CO}_{2}$ derived from methane oxidation at cold seeps (Lösekann et al. 2008). Such $\delta^{13} \mathrm{C}$ signatures differ substantially from photosynthesized organic carbon from phytoplankton $\left(\delta^{13} \mathrm{C}\right.$ typically -20 to $-25 \%$ ) and ice algae (typically -15 to $-20 \%$ ) (Hobson et al. 1995, Søreide et al. 2006). Hence, due to differences in the carbon end-member isotope compositions caused by different carbon fixation pathways, trophic interactions, and carbon-source $\delta^{13} \mathrm{C}$ signatures, ${ }^{13} \mathrm{C} /$ ${ }^{12} \mathrm{C}$ ratios in biomass provide a valuable tracer of CBC in marine food webs (Robinson \& Cavanaugh 1995, Zapata-Hernández et al. 2014, Ferrier-Pagès \& Leal 2018).

In addition to their importance in the context of nutrient allocation for benthic communities, cold seeps have other ecosystem functions and play an important role in structuring faunal community composition. Seepage of fluids and gases in the sediment creates strong geochemical gradients that influence organisms on multiple spatial scales (Bergquist et al. 2005, Bowden et al. 2013, Levin et al. 2016) and mod- 
ulates local seabed biodiversity and heterogeneity (Vismann 1991, Sibuet \& Olu 1998). At cold seeps, chemosymbiotic energy sources can give rise to highly specialized communities thriving in high abundances and at high biomass (Sibuet \& Olu 1998, Bergquist et al. 2005, Vanreusel et al. 2009). Moreover, excess bicarbonate produced during AOM can precipitate and form methane-derived authigenic carbonate pavements (hereafter referred to as carbonate outcrops) on the seafloor (Bohrmann et al. 1998). These carbonate outcrops constitute important features, adding 3dimensional (3D) structure and enhancing faunal habitat complexity with respect to the surrounding seafloor (Carney 1994, Levin et al. 2016, Åström et al. 2018).

Cold seeps occur in all the world's oceans (Sibuet \& Olu 1998, Vanreusel et al. 2009, Levin et al. 2016), including the Arctic (Decker et al. 2012, Paull et al. 2015, Savvichev et al. 2018). Natural methane seeps have also been found in the Barents Sea, around the Svalbard archipelago, where gas seepage likely results from the dissolution of hydrate reservoirs in the sub-seabed caused by post-glacial isostatic rebound from the last glacial maximum (LGM) (Portnov et al. 2016, Serov et al. 2017) and tectonic stress (PlazaFaverola \& Keiding 2019). Several of these seeps have been intensely studied with respect to geophysical and geochemical aspects (e.g. Sahling et al. 2014, Andreassen et al. 2017, Serov et al. 2017), and to a lesser extent, their ecological significance (Åström et al. 2016, 2018, Sen et al. 2018a). However, the trophic structure within these ecosystems is poorly understood.

Studies on carbon cycling within Svalbard fjords and the adjacent offshore shelves have demonstrated the relative importance of carbon sources from terrestrial origin versus phytoplankton, macroalgae, and ice-algae contributions to the Arctic marine food web (e.g. Søreide et al. 2006, Holding et al. 2017). The contribution of CBC from cold seeps to high-Arctic benthic food webs has scarcely been investigated outside the area of the Håkon Mosby mud volcano (HMMV) at the western border of the Barents Sea slope (1200 m water depth) (e.g. Gebruk et al. 2003, Decker \& Olu 2012). To our knowledge, the importance of $\mathrm{CBC}$ in fueling benthic food webs has never been assessed at cold seeps on the Barents Sea shelf.

Our goal was to examine to what extent CBC originating from methane sources at cold seeps in the Barents Sea is incorporated into benthic invertebrates in these habitats. Furthermore, we investigated the macro-infaunal community structure to compare the communities at cold seep stations within the Barents
Sea with non-seep stations as references. Using community analysis of faunal composition as well as stable isotope analyses, we evaluated the impact of cold seeps and environmental variables on benthic community structure and interactions at multiple sites. The community analysis elucidated which dominant faunal components drive observed community structure patterns at the cold seeps, while the isotopic measurements provided insights into the role of CBC within the food web.

\section{MATERIALS AND METHODS}

\subsection{Study areas}

The Barents Sea is a continental shelf sea located between the mainland of northern Norway and the Svalbard archipelago. To the west, it borders the Norwegian Sea (North Atlantic Ocean), and to the east, it is separated from the Kara Sea by the island of Novaja Zemlja (Fig. 1). The Barents Sea shelf is influenced by both warm and saline Atlantic water from the southwest, and cold Arctic water masses from the northeast, forming the oceanic boundary known as the polar front (Loeng 1991). The average water depth in the Barents Sea is approximately $230 \mathrm{~m}$, and

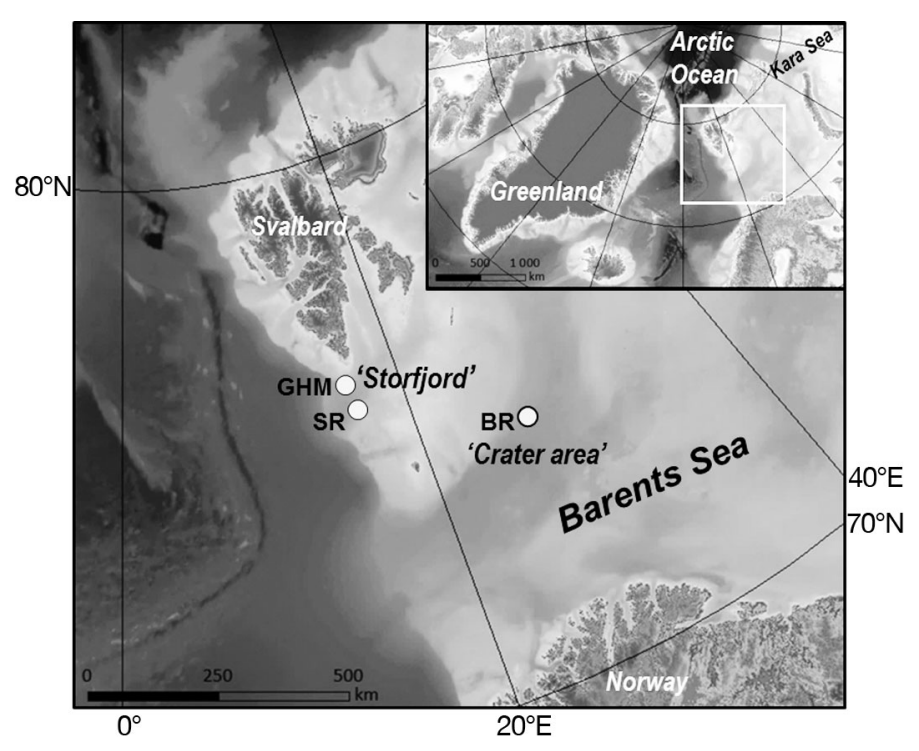

Fig. 1. Sites used in this study (circles), located in the western and central Barents Sea region. GHM: gas hydrate mounds $\sim 380 \mathrm{~m}$ deep, SR: Storfjordrenna seep $\sim 350 \mathrm{~m}_{\text {; }} \mathrm{BR}$ : Bjørnøyrenna crater field $\sim 335 \mathrm{~m}$. SR, GHM, and reference non-seep control station collectively are referred to as 'Storfjord'; BR stations including the reference non-seep control site are referred to as the 'Crater area.' Bathymetry from IBACO v. 3.0 (Jakobsson et al. 2012) 
bathymetry is characterized by numerous troughs, banks, and post-glacial features including many wedges and iceberg plough marks (Patton et al. 2017).

Cold seeps in which seabed emissions have been found to originate from sub-seabed dissociating gas hydrates have been documented at numerous locations along the western Svalbard margin. Indeed, several of the seeps occur near the predicted upper depth limit of the gas hydrate stability zone, resulting in a release of methane from these gas reservoirs (Sahling et al. 2014, Portnov et al. 2016, Serov et al. 2017). In the western Barents Sea, 2 such locations have been identified in the outer part of Storfjordrenna, with clear evidence for sub-surface gas deposits and hydrocarbon seepage (Fig. 1). The southernmost location is known as the Storfjordrenna seep field (SR). This site is characterized by a predominantly soft-bottom plain, where small carbonate outcrops, chemosymbiotic polychaete colonies and microbial mats have been observed at a water depth of $350 \mathrm{~m}$ (Åström et al. 2016). Approximately $30 \mathrm{~km}$ northwest of SR, a cluster of methane-seeping gas hydrate mounds (GHMs) was recently discovered (Serov et al. 2017). These rounded domes are a few hundred meters in diameter and rise approximately 8-10 $\mathrm{m}$ from the seabed at water depths of around $380 \mathrm{~m}$. Several of the GHMs contain gas hydrates in near-surface sediments, display elevated concentrations of dissolved methane in the sediment pore water, and are actively emitting methane gas into the water column (Hong et al. 2017, Serov et al. 2017). Further to the east into the central Barents Sea, an area with verified seabed seepage activity, craters, and crater-mound complexes has been documented in the Bjørnøyrenna trough (BR) (Fig. 1) (Solheim \& Elverhøi 1993, Andreassen et al. 2017). A few of these seeping craters and adjacent areas have been investigated for their macrobenthic community structure (Åström et al. 2016).

The above-described sites were the target of our study. These cold seeps were all once covered by the Barents Sea Ice Sheet (BSIS) during the LGM. Modeling and paleo-oceanographic records suggest that the outer SR became ice-free around $19000 \mathrm{cal}$. yr BP (Rasmussen et al. 2007, Serov et al. 2017), and that the central part of the Barents Sea, the BR, was icefree around 15000 yr BP (Andreassen et al. 2017, Patton et al. 2017). Evidence of dynamic paleo-ice stream activity at the seabed, such as mega-scale glacial lineations, indicate that the large seabed structures associated with cold seeps in this study (mounds and craters) were formed after the deglacia- tion of the BSIS from the region and can be considered relatively young formations (at least on a geological time-scale: <15000 yr BP) (Serov et al. 2017, Andreassen et al. 2017).

We designated 2 main sampling regions within the study area: the 'Storfjord' and the 'Crater area', which refer to the name of the trough and the characteristic depressions, respectively (Fig. 1, Table 1). Storfjord consists of the sites around the SR seep field (SR 1, SR 15) and the GHMs (GHM 2, GHM 3), as well as paired non-seep reference stations (SR 2C and GHM C). The Crater area refers to Stns BR 3, BR 15, BR 16, and a non-seep reference site (BR C) located in the BR trough (see Table 1 for details).

\subsection{Benthic sampling}

We collected faunal and sediment samples from 3 verified locations of methane seepage (BR, GHM, SR) (Fig. 1). Additionally, we sampled at non-seepage (i.e. control) locations. All sampling was conducted from the R/V 'Helmer Hanssen' during the Arctic spring/ summer seasons in 2014, 2015, and 2016 (Table 1). Locations of active hydrocarbon seepage were selected based on previous surveys in the region (Solheim \& Elverhøi 1993, Åström et al. 2016, Hong et al. 2017), and where acoustically detected gas/bubble streams (i.e. acoustic flares) were recorded with a single beam echo sounder (Simrad EK60; frequencies 18 and $38 \mathrm{kHz}$ ). Vertical CTD hydrocasts (SBE 9 plus sensor) were performed at each station prior to sampling on the seafloor. Benthic sampling for faunal community analyses in 2014 was conducted where acoustic reflections from bubble streams where observed in the water column (see detailed description in Åström et al. 2016), using a van Veen grab $\left(0.1 \mathrm{~m}^{2}\right)$. During the 2015 survey, samples were collected in areas where characteristic seep features, such as flares, microbial mats, and carbonate outcrops, were identified through seafloor imagery using a towed camera-guided multicorer with CTD sensor (see details in Åström et al. 2018). In 2016, seafloor imaging was carried out using a remotely operated vehicle (ROV; Sperre $30 \mathrm{~K}$, www. ntnu.edu/aur-lab/rov30k) operated by the Norwegian University for Science and Technology. Video recording and stereo camera imaging (resolution: $1360 \times$ 1024 pixels) allowed pinpointing areas of active gas ebullition and detailed investigation of the seafloor structures including carbonate outcrops and microbial mats (Sen et al. 2018a). In addition to visual investigations of the sea floor using the towed camera and ROV in 2015 and 2016, we collected sediment samples for 


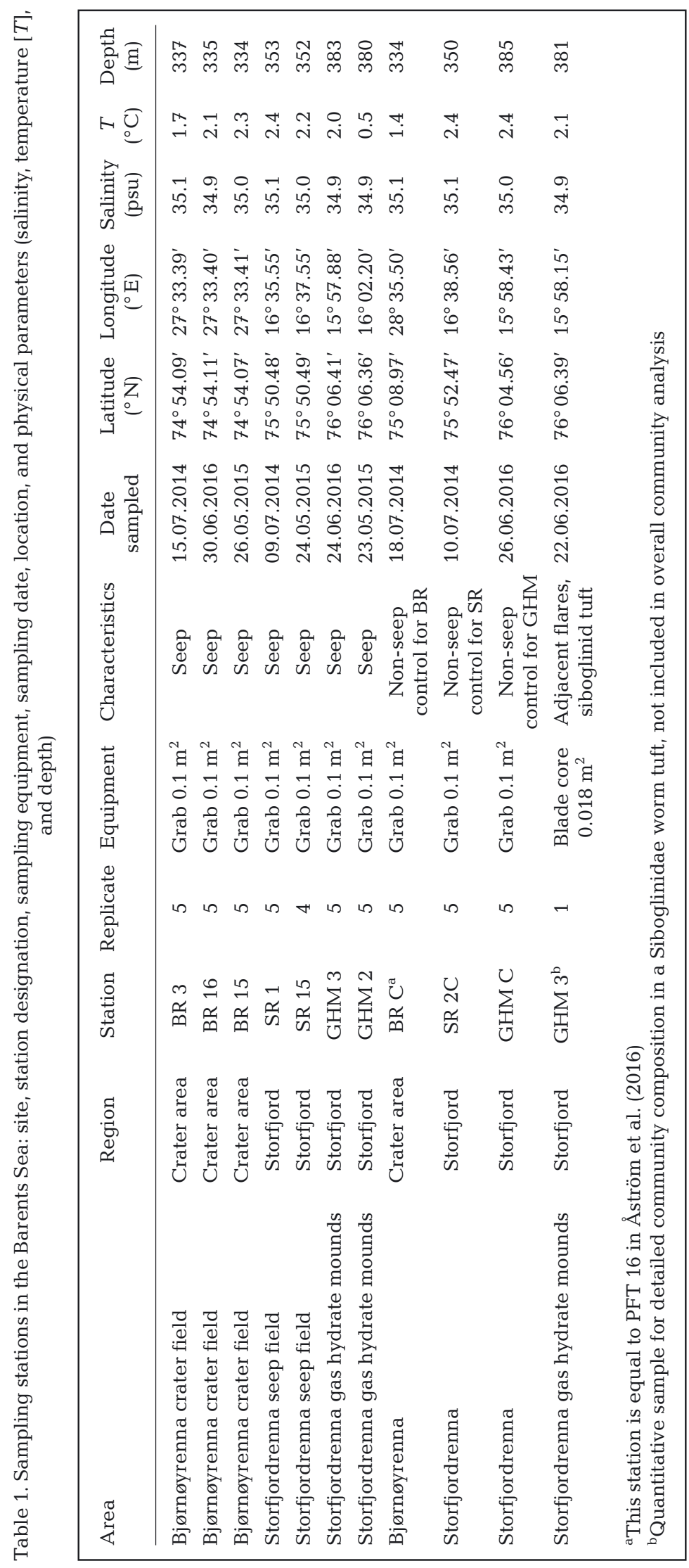

quantitative faunal analyses with van Veen grabs $\left(0.1 \mathrm{~m}^{2}\right)$. For the same purpose, we also included one sample taken with a blade core $\left(0.018 \mathrm{~m}^{2}\right)$ from the ROV in a tuft of chemosymbiotic polychaetes in the vicinity (within meters) of a bubble stream of seeping gas in order to obtain a detailed overview of the faunal composition in this habitat (Table 1). In total, we sampled 10 van Veen grab stations from designated seeps and non-seep control sites in order to characterize macrofaunal communities $(\geq 500 \mu \mathrm{m})$ (Table 1). Five replicate grabs were taken at each station for quantitative faunal analysis, except for at one station (SR 15) where only 4 replicates were collected. We took an additional grab sample at each station for the determination of sediment characteristics including porosity, grain size, total organic carbon (TOC), and benthic pigments (chlorophyll $a$ [chl a] and phaeopigments [PhP]).

In addition to the above samples used for community quantification, a number of faunal samples were collected from different types of sampling gear and devices such as grabs, sediment cores, triangle dredges, and through 'manual' ROV-sampling, i.e. scooping with a benthic 'butterfly' net. These samples were used for bulk stable isotope analyses $\left(\delta^{13} \mathrm{C}\right.$ and $\delta^{15} \mathrm{~N}$ ) of benthic organism tissue (Hobson \& Welch 1992, Hobson et al. 1995, Søreide et al. 2006) to assess food web and trophic level (TL) interactions. Animals for isotopic analysis were sorted and identified immediately after collection, and for some taxa (primarily for mud-dwelling echinoderms), we included a 1-2 d depuration period in a dark cold-room onboard the vessel in order to clear the guts of ingested sediment. All organisms collected for isotope measurements were stored frozen $\left(-20^{\circ} \mathrm{C}\right)$ prior to further processing and laboratory analysis.

\subsubsection{Macrofaunal community characterization}

Benthic samples for macrofaunal community structure analysis were sieved immediately onboard the vessel using a $500 \mu \mathrm{m}$ mesh. Material retained on the sieve was fixed in formaldehyde $(4 \%)$, mixed with rose-bengal for staining live tissue, and the solution was buffered with borax (sodium tetra-borate decahydrate). In the labo- 
ratory, samples were sorted and identified to the lowest possible taxon and stored in $80 \%$ ethanol. This procedure followed the ISO 16665:2014 fieldwork protocol to ensure consistency and quality control of benthic faunal surveys. Organisms were first separated into main phyletic groups: Crustacea, Echinodermata, Mollusca, Polychaeta, and 'diverse' (containing members of the taxonomic groups Brachiopoda, Chordata, Cnidaria, Hemichordtata, Nemertea, Oligochaeta, Platyhelminthes, Priapulida, and Sipuncula). Taxonspecific counts were compiled after each individual was identified to species or the lowest possible taxonomic level. Individuals of each phyletic group were weighed collectively to obtain aggregated wet weight of the respective groups. True planktonic taxa were excluded from the counts, as were Foraminifera and Nematoda, which are not quantitatively retained on a $500 \mu \mathrm{m}$ mesh. Colonial taxa such as Porifera, Bryozoa, and Hydrozoa were excluded in the faunalabundance analysis, but their biomass was included in the 'diverse' phyletic group.

\subsubsection{Benthic pigment and sediment analysis}

Sediment-bound chl a and PhP were quantified in sediment samples as indicators of photosynthetically derived organic material deposited on the seafloor. Sediment chl a indicates relatively recently produced material, whereas $\mathrm{PhP}$ represent the degradation product of chl a. Surface-sediment pigment concentrations (upper 0-2 cm) from sediment samples were analyzed by fluorometery (Holm-Hansen et al. 1965). Sediments and filters for chl $a$ and PhP samples were extracted with acetone for 12-24 h, covered with aluminum foil and kept in a freezer. After extraction, samples were centrifuged, decanted, and measured for fluorescence using a Turner Design Model 10 AU fluorometer before and after acidification with hydrochloric acid (1 M). The measured concentrations were corrected for sediment porosity.

Porosity of sediment samples was determined using a wet-dry method, where pre-weighed vials of known volume were filled with sediment, weighed, dried at $60^{\circ} \mathrm{C}$ until all water evaporated, and reweighed. Density of the sediment was calculated using the wet weight and the total water-filled pore space of the sample (Zaborska et al. 2008).

Sediment grain size (fraction of pelite $<0.63 \mu \mathrm{m}$ ) and TOC were determined by subsampling surface $(0-2 \mathrm{~cm})$ sediments (minimum $50 \mathrm{~g}$ ) from grab samples. Grain size was determined according to Bale \& Kenny (2005). For TOC, samples were dried and homogenized and first, total carbon (TC) was determined. Subsequently, acid $(\mathrm{HCl})$ was added to another sample aliquot and total inorganic carbon (TIC) was quantitatively removed. After acidification, samples were dried at $70^{\circ} \mathrm{C}$. Analysis of both the TC and TOC content were performed on a Shimadzu SSM 5000 and Elementar Vario Cube, where the samples were combusted at $950^{\circ} \mathrm{C}$ and the resulting $\mathrm{CO}_{2}$ was quantified using a flame ionization detector.

\section{3. $\delta^{13} \mathrm{C}$ and $\delta^{15} \mathrm{~N}$ analysis}

For stable isotope analyses, smaller organisms were processed as whole units, whereas specific tissues were sampled from larger individuals (e.g. muscle, tail, intestine, foot) depending on taxa. Samples were freeze-dried for $24 \mathrm{~h}$ and the dried tissue was homogenized and weighed into tin capsules, $\sim 1.5 \mathrm{mg}$ tissue sample ${ }^{-1}$. For sediments, $\sim 25 \mathrm{mg}$ of freezedried material was weighed into tin capsules. Particulate organic matter (POM) samples were derived from seawater samples (2.5-3 l) filtered onto precombusted membrane filters $(0.22 \mu \mathrm{m}, 4.7 \mathrm{~cm}$; Merck Millipore) and stored frozen prior to freeze-drying. $\delta^{15} \mathrm{~N}$ and $\delta^{13} \mathrm{C}$ composition of bulk material (tissue and sediments) was measured using an elemental analyzer coupled to an isotope ratio mass spectrometer (EA-IRMS; INTEGRA2; Sercon). The combustion and reduction reactors of the instrument were operated at 1050 and $600^{\circ} \mathrm{C}$, respectively. Gas chromatographic separation of the combustion and reduction products $\left(\mathrm{N}_{2}\right.$ and $\left.\mathrm{CO}_{2}\right)$ was achieved on a packed column (stainless steel, $50 \mathrm{~cm}, 1 / 4$ " o.d., Carbosieve G, 60/80 mesh; Analytical Columns) at a temperature of $55^{\circ} \mathrm{C}$, with $\mathrm{He}$ as a carrier gas $\left(55 \mathrm{ml} \mathrm{min}^{-1}\right)$. The raw nitrogen and carbon isotopic data were blank-, linearity, and drift-corrected by means of 2-point calibrations based on EDTA and IAEA-N-2 or EDTA and IAEA-CH-6 standards, respectively. Isotopic compositions are reported in the conventional $\delta$-notation, as $\delta^{15} \mathrm{~N}$ and $\delta^{13} \mathrm{C}$ in per mille relative to air and VPDB (Vienna Pee Dee Belemnite), respectively. Reproducibility based on duplicate analyses of samples, as well as internal and external standards was better than $\pm 0.25 \%$ or for $\delta^{15} \mathrm{~N}$ and better than $0.1 \%$ for $\delta^{13} \mathrm{C}$.

We calculated the TL of taxa to determine their trophic position in the food web (i.e. first-order consumer [grazer], second-order consumer [predator], etc.). As a first step, we assumed photosynthetic POM to be the sole carbon and nitrogen source in the targeted areas. The POM $\delta^{13} \mathrm{C}$ and $\delta^{15} \mathrm{~N}$ values determined in this study, integrated with published values 
collected under similar conditions (Søreide et al. $2006,2008)$, were used as a baseline isotopic signature for estimating the trophic position of organisms in the food web (i.e. $-25.1 \%$ for $\delta^{13} \mathrm{C}$, with a range of -23.5 to $-27.3 \%$, and $4.0 \%$ for $\delta^{15} \mathrm{~N}$, with a range of $3.9-4.4 \%$ ). We assumed stepwise isotope fractionation values, with TLs of $3.4 \%$ for nitrogen and $0.6 \%$ for carbon (Hobson \& Welch 1992, Søreide et al. 2006). Based on Søreide et al. (2006), the TL was then calculated as:

$$
\mathrm{TL}=\left[\left(\delta^{15} \mathrm{~N}_{\text {Org. }}-\delta^{15} \mathrm{~N}_{\mathrm{POM}}\right) / 3.4\right]+1
$$

where $\delta^{15} \mathrm{~N}_{\text {Org }}$. is the $\delta^{15} \mathrm{~N}$ value of a given organism and $\delta^{15} \mathrm{~N}_{\text {POM }}$ is the TL baseline for the system. $\delta^{13} \mathrm{C}$ values more negative than the baseline of $-25.1 \%$ are indicative of the contribution from a ${ }^{13} \mathrm{C}$-depleted carbon source (i.e. here considered a chemosynthesis-based source). We used end-member calculations for the isotopic composition of potential food sources to determine the relative contribution of photosynthesis-based carbon vs. CBC at the targeted seeps. The calculations were based on the results from our stable isotope analyses and values from Søreide et al. (2006, 2008). Hence, for organisms exhibiting relatively low $\delta^{13} \mathrm{C}$ values, a 2-component mixing equation was used to approximate the fraction $\left(X_{\text {fraction }}\right)$ of carbon that originated from the assimilation of $\mathrm{CBC}$ originating from the seabed seepage of hydrocarbons versus POM. The following equation was applied:

$X_{\text {fraction }}=\left(\delta^{13} \mathrm{C}_{\text {Org. }}-\delta^{13} \mathrm{C}_{\mathrm{POM}}\right) /\left(\delta^{13} \mathrm{C}_{\mathrm{CBC}}-\delta^{13} \mathrm{C}_{\mathrm{POM}}\right)$

Here, analogous to Eq. (1), $\delta^{13} \mathrm{C}_{\text {Org. }}$ is the $\delta^{13} \mathrm{C}$ value of the biomass of a specific individual organism, and $\delta^{13} \mathrm{C}_{\mathrm{POM}}(-25.1 \%$ ) represents the baseline value for a solely photosynthetic carbon source. $\delta^{13} \mathrm{C}_{\mathrm{CBC}}$ represents the $\delta^{13} \mathrm{C}$ value of chemosynthetic sources.

Few organisms can directly rely on methane as an energy source i.e. AOM and microbial aerobic methane-oxidation (MOx) mediating communities, wherefore in sediment communities AOM is more important (Reeburgh 2007, Knittel \& Boetius 2009). Given the carbon isotope fractionation $(\varepsilon)$ that occurs during $\mathrm{AOM}(\varepsilon \approx 12-38 \%$ ) (Holler et al. 2009), and the $\delta^{13} \mathrm{C}$ of the methane itself, the AOM-biomass at the investigated seeps (which can be incorporated in the biomass of benthic organisms) will be markedly depleted in ${ }^{13} \mathrm{C}$ relative to photosynthetically derived carbon sources. Methanotrophs, however, are certainly not the only microorganisms that can incorporate methane-derived carbon. Via AOM coupled to sulfate reduction, hydrogen sulfide $\left(\mathrm{H}_{2} \mathrm{~S}\right)$ and dissolved inorganic carbon (DIC), CBC becomes bio- available in an ecosystem through SOB (Southward et al. 1986, Brooks et al. 1987, Dubilier et al. 2008). Hence, SOB can function as a carbon bridge between chemical energy sources (in this study, seepage of methane from the seeps) and fauna; and in this way, various organisms inhabiting seeps can benefit from chemosynthesis.

To estimate the contribution of $\mathrm{CBC}$ in this study, we used different approaches: firstly, we used the $\delta^{13} \mathrm{C}$ value of methane, $\delta^{13} \mathrm{C}=-47 \%$, sampled at the GHM (Serov et al. 2017) as the key end-member. We also provide calculations using the most negative CBC end-member signal of $-85 \%$, i.e. we assume that the CBC is strongly fractionated and of AOM origin $\left(\mathrm{CBC} \delta^{13} \mathrm{C}=-47 \%\right.$, $\varepsilon$ up to $-38 \%$; Holler et al. 2009). Finally, we made calculations based on the least depleted $\mathrm{CBC}$ end-member, $-35 \%$ o (i.e. all carbon assumed to be derived from thiotrophic symbiotic species, i.e. SOB). Here, we used a combination of known values from the literature for SOB (Southward et al. 1986, Robinson \& Cavanaugh 1995, Decker \& Olu 2012) (ranging between -27 and $-35 \%$ o). Furthermore, we integrated in our isotope balance considerations the carbon isotopic composition of the siboglinids-reduced sediment, and bacterial mat sediment samples from this study, where we consider input of SOB. These abovementioned estimates result in an average $\delta^{13} \mathrm{C}$ of SOB $\sim-35 \%$. For our isotope balance model, we assumed that carbon fixation occurs primarily via the CBB-cycle (Robinson \& Cavanaugh 1995, Hügler \& Sievert 2011). rTCA has been shown to be a more common carbon fixation pathway at vents and is considered a minor contributor to ecosystem carbon fixation in most seep systems (Hügler \& Sievert 2011, Thiel et al. 2012). Estimates on the CBC (from both AOM and SOB) into investigated taxa is presented in Table S1 in the Supplement at www.int-res.com/articles/suppl/m629p019 _supp.pdf.

In addition to assuming that POM derived from the water column is the sole photosynthetic energy source, we applied the same 2-component mixing approach (Eq. 2) using a $\delta^{13} \mathrm{C}$ of $-20.7 \%$ for sedimentary organic matter $(\mathrm{SOM})$, i.e. $\delta^{13} \mathrm{C}_{\mathrm{SOM}}$ instead of $\delta^{13} \mathrm{C}_{\mathrm{POM}}$. This approach allows a refined estimate of the extent to which different benthic organisms have incorporated carbon from chemosynthetic sources relative to SOM (which includes deposited, refractory organic material, and sediment-bound chlorophyll pigments) (Zapata-Hernández et al. 2014, Alfaro-Lucas et al. 2018). If we consider that most of the animals in this study were benthic (i.e. sediment dwelling, deposit feeders or organisms preying on 
deposit feeders), this approach examines the possible contribution of CBC specifically to the benthos.

In summary, for the end-member calculations (Eq. 2) of potential food sources in the system and to determine the relative contribution of the chemical energy carbon sources at the seeps, we considered the following baseline values for carbon: $\mathrm{C}_{\mathrm{POM}}$ $-25.1 \%$, $\mathrm{C}_{\mathrm{SOM}}-20.7 \%$, $\mathrm{C}_{\mathrm{CH} 4}-47 \%$, $\mathrm{C}_{\mathrm{SOB}}-35 \%$, and $\mathrm{C}_{\text {frac.AOM }}-85 \%$.

\subsection{Statistical analysis}

Diversity indices, including species richness $(S)$, Hurlbert rarefaction index $\left(\mathrm{ES}_{(100)}\right)$, evenness $\left(J^{\prime}\right)$ and Shannon-Wiener diversity $\left(H^{\prime} \log _{e}\right)$, were calculated based on total faunal abundances (Hurlbert 1971). We used faunal abundance to create a non-metric multidimensional scaling plot (nMDS) and cluster analysis based on the Bray-Curtis similarity matrix. Abundance data were standardized and transformed (single square-root) prior to analysis, in order to control for the effect of large variability among replicates and to balance highly abundant and rarer taxa. ANOSIM was used to test the significance of the cluster results (Clarke \& Gorley 2006).

We calculated Pearson correlation coefficients (r) to determine individual pairwise relationships between environmental variables and univariate faunal community data using Sigma Plot (v.12.5; Systat Software). Moreover, we used multivariate analysis to demonstrate the influence of environmental variables on overall faunal abundance at any given station, using the statistical computing program R. A canonical correspondence analysis (CCA) with multivariate constrained ordination was run to examine the ordination of station faunal abundance (we included only taxa that contributed to more than $1 \%$ of the overall faunal abundance in the entire data set) in relation to standardized environmental variables (Oksanen et al. 2016). Environmental variables included water depth, salinity, bottom water temperature, and sediment characteristics such as grain size (fraction $<0.63 \mathrm{~mm})$, TOC (\%), and benthic pigments (total concentration of chl $a$ and $\mathrm{PhP}$ ). In addition, we added total faunal biomass and $S$ as explanatory community parameters.

SIMPER analysis was used to test similarities among taxon abundances between clusters seen in the nMDS plot. The clusters were grouped according to overall region, categorized either as Storfjord or Crater area, with the exception of 5 samples that formed a separate cluster. A refined control of the samples that were grouped for respective regions included samples both from non-seep controls as well as samples collected at the seeps but without clear evidence of strong impact from the seepage (hereafter classified as 'peripheral' seep samples). The latter cluster in the nMDS plot included 5 separate samples that grouped together regardless of region, and we categorized them as 'strong seep influence'. These samples were all characterized by high abundance of chemosymbiotic siboglinids and displayed strong impact from the hydrocarbon seepage (i.e. strongly reduced, black and gassy sediments, and presence of carbonate rocks). Furthermore, in the SIMPER analysis, we tested the similarities on faunal abundances between these strong seep-influenced samples and all remaining samples, categorized as 'others' (including peripheral seep samples and non-seep controls). These analyses were conducted with Primer v.6 (Clarke \& Gorley 2006).

\section{RESULTS}

\subsection{Community structure and environmental influences}

We identified 312 different taxa comprising nearly 40000 individuals from 10 grab stations and 49 replicate samples in total. The overall average $( \pm \mathrm{SE})$ faunal abundance was $7936 \pm 1172$ ind. $\mathrm{m}^{-2}$, but was highly variable among stations, ranging from 457515878 ind. $\mathrm{m}^{-2}$ (Fig. 2, Table 2). The 2 most numerous taxa were siboglinid polychaetes (clade Frenulata)

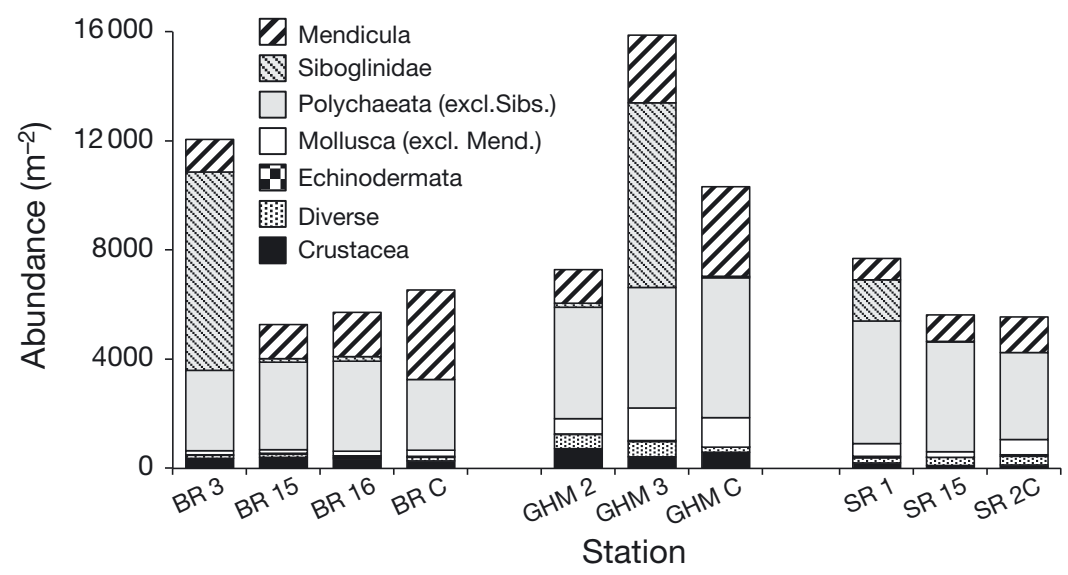

Fig. 2. Faunal abundances aggregated by station. See Table 1 for station information 
Table 2. Faunal and environmental characteristics at each station; see Table 1 for station abbreviations. ES $(100)$ : Hurlbert index; TOC: total organic carbon

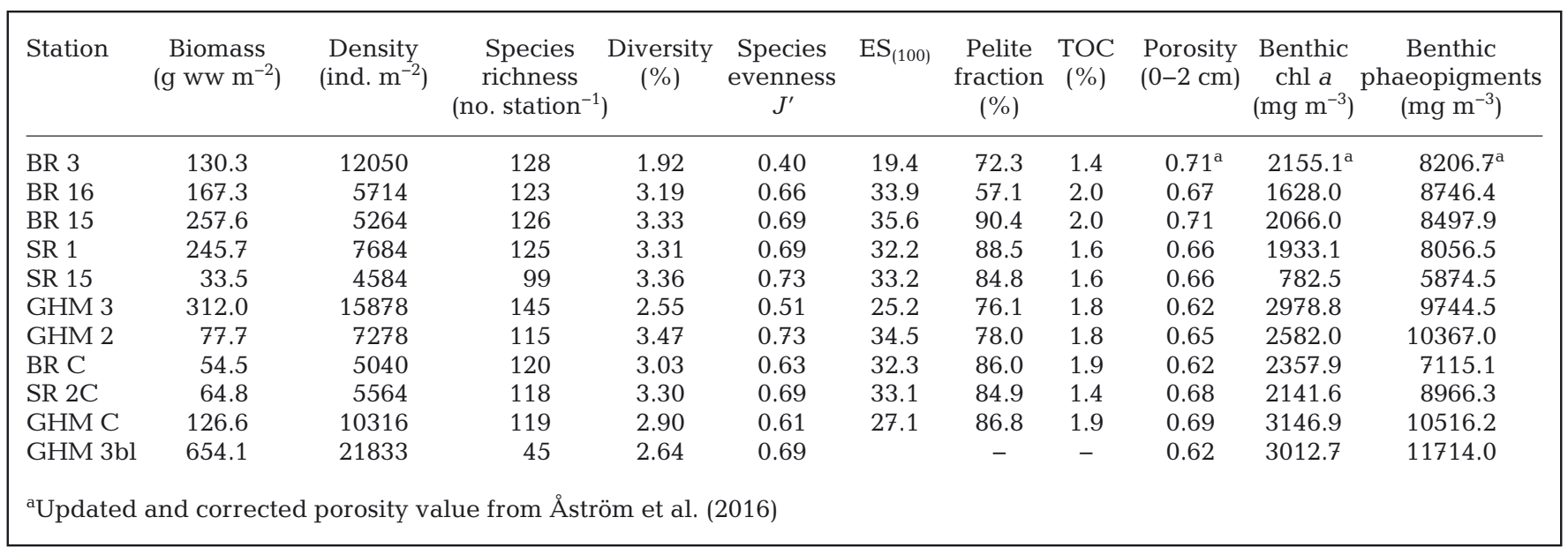

and Mendicula cf. pygmaea bivalves (Fig. 3), contributing 20.3 and $19.8 \%$, respectively, to the total faunal abundance. Their average faunal abundances across all stations were $1607 \pm 914$ and $1569 \pm 248$ ind. $\mathrm{m}^{-2}$, respectively. Siboglinids however, were absent from 2 stations (SR 2C and BR C), whereas $M$. cf. pygmaea was present at all stations. At stations categorized by strong seep-influenced replicates (GHM 3, SR 1, and BR 3), the chemosymbiotic siboglinids and M. cf. pygmaea bivalves encompassed $56.2 \%$ of total faunal abundance (Table 3). At non-seepage control stations (GHM C, SR 2C, and BR C), M. cf. pygmaea was the most common species, comprising over $30 \%$ of total abundance, followed by the polychaete Prinospio cirrifera (Table 3). In one replicate (van Veen grab sample, $0.1 \mathrm{~m}^{2}$ ) from the GHM 3 seep, we recorded extremely high abundances of siboglinid polychaetes and $M$. cf. pygmaea (equivalent to 32120 and 4770 ind. $\mathrm{m}^{-2}$, respectively).

Benthic biomass was highly variable among stations (Table 2) (overall mean $\pm \mathrm{SE}=147.0 \pm 30.4 \mathrm{~g}$ wet weight $[\mathrm{ww}] \mathrm{m}^{-2}$ ), with Polychaeta contributing the most to the overall biomass $(56.3 \%)$, followed by Mollusca $(22.7 \%)$. There were trends towards higher faunal abundance and biomass at seeps compared to non-seep control samples; however, these patterns were not statistically significant owing to the high variability of sampled individuals among replicates.

The nMDS and multivariate analysis based on total faunal abundance at the replicate level showed 2 different clusters $(R=0.81, p<0.001)$, separated by $36 \%$ similarity (Fig. 4a). One cluster included 5 individual replicates from Stns GHM 3, SR 1, and BR 3, while the second cluster included all remaining replicates both from non-seep paired controls and the peripheral seep replicates, collected at the seeps but lacking obvious signs of strong seep influence (as we defined in Section 2.4). All replicates in the latter cluster were grouped according to their station and overall sampling location (Fig. 4a). Furthermore, there was a distinct regional separation (44\% similarity), grouping replicates from Storfjord and Crater area in addition to the separation from the first cluster that included the 5 strong seepinfluenced replicates from Stns GHM 3, SR 1, and BR 3 (Fig. 4a). These 3 clusters were significantly different from each other $(\mathrm{R}=0.87, \mathrm{p}<0.001)$. A refined hierarchical cluster analysis and dendrogram including only the non-seep paired controls and the significantly different cluster of strong seep-influenced samples in Fig. 4a further underscores that these 5 replicates from GHM 3, SR 1, and BR 3 were distinctly different with regards to their faunal composition compared to other replicates (Fig. 4b).

In the CCA, the composite-station (across-stage average) abundance, biomass, and $S$ were plotted against the environmental variables TOC, grain size fraction, temperature, benthic pigments, porosity, salinity, and depth (Fig. 5). Three stations (GHM 3, SR 1, and BR 3) were clearly separated from all other stations along the first axis, which explained $48.7 \%$ of the variability in the data (CCA I; Fig. 5). These stations comprised similar environmental variables and were also grouped by high abundances of siboglinids, high $S$, and high biomass. The other stations, including both reference non-seep controls and the peripheral seeps, clustered together; however, these stations were also separated by overall main region, either belonging to Storfjord or Crater area along the second axis (CCA II; Fig. 5), which explained 23.1\% of the observed variability. The slightly shallower 

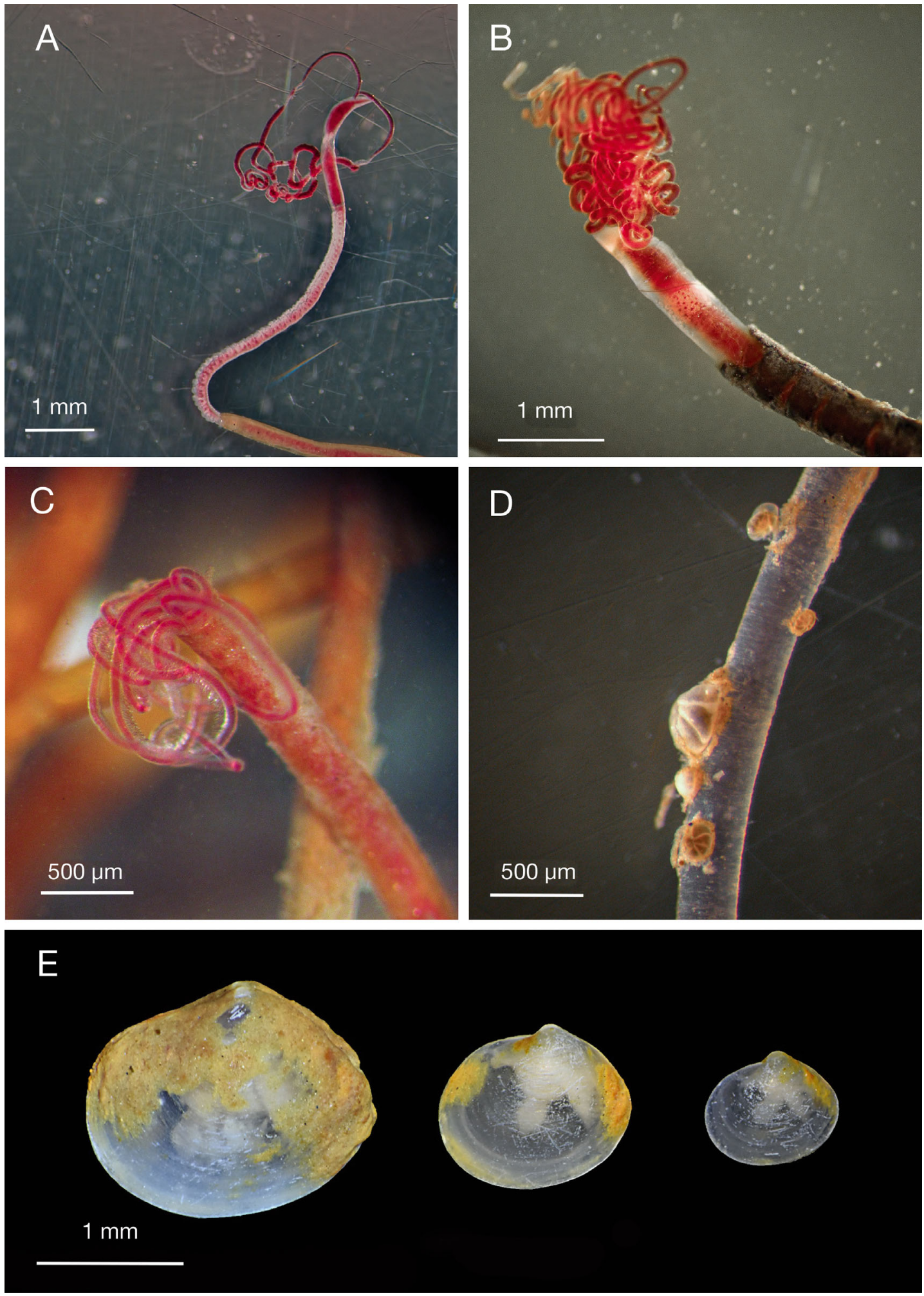

Fig. 3. The 3 chemosymbiotic frenulates found in the study region: (A) possible Diplobrachia sp. (B) Oligobrachia sp. CPLclade (Sen et al. 2018b), and (C) possible Polybrachia sp. (note the tentacles with pinnules protruding out of its tube). (D) Epibenthic foraminifera (Cibicidoides sp.) attached to an Oligobrachia sp. tube. (E) Mendicula cf. pygmaea bivalves occurred at high abundances at all stations, regardless of seepage activity. These individuals were collected at the Bjørnøyrenna seeps. Yellow, brownish color on the bivalve shell is encrusting material 
Table 3. Density of the top 10 most common taxa and their relative contribution to total faunal abundance; see Table 1 for station abbreviations. (A) GHM 3 blade core from a worm tuft of chemosymbiotic frenulates, (B) 'strong seep-influenced' Stns GHM 3, SR 1, and BR 3, (C) non-seep control Stns GHM C, SR 2C and BR C

\begin{tabular}{|c|c|c|c|}
\hline me & $\begin{array}{l}\text { No. ind. } \mathrm{m}^{-2} / \\
\text { an ind. } \mathrm{m}^{-2}( \pm \mathrm{SD})\end{array}$ & $\begin{array}{c}\text { Total faunal } \\
\text { abundance (\%) }\end{array}$ & $\begin{array}{c}\text { Cumulative } \\
(\%)\end{array}$ \\
\hline \multicolumn{4}{|l|}{ (A) Blade core GHM 3} \\
\hline Frenulata indet. & 7667 & 35.1 & 35.1 \\
\hline Mendicula cf. pygmaea & 2500 & 11.5 & 46.6 \\
\hline Cossura longocirrata & 1389 & 6.4 & 53.0 \\
\hline Galathowenia oculata & 1278 & 5.9 & 58.9 \\
\hline Yoldiella solidula & 1111 & 5.1 & 64.0 \\
\hline Chaetozone sp. & 1056 & 4.8 & 68.8 \\
\hline Aphelochaeta sp. & 722 & 3.3 & 72.1 \\
\hline Polycirrus medusa & 611 & 2.8 & 74.9 \\
\hline Maldane sarsi & 556 & 2.5 & 77.4 \\
\hline Paradoneis lyra & 500 & 2.3 & 79.7 \\
\hline Total: & & & 79.7 \\
\hline \multicolumn{4}{|c|}{ (B) Seeps (GHM 3, SR 1 and BR 3) } \\
\hline Frenulata indet. & $5187(1062)$ & 43.7 & 43.7 \\
\hline Mendicula cf. pygmaea & $1485(297)$ & 12.5 & 56.2 \\
\hline Spiochaetopterus typicus & $377(182)$ & 3.2 & 59.4 \\
\hline Yoldiella solidula & $363(166)$ & 3.1 & 62.5 \\
\hline Galathowenia oculata & $311(101)$ & 2.6 & 65.1 \\
\hline Prionospio cirrifera & $277(72)$ & 2.3 & 67.4 \\
\hline Cossura longocirrata & $269(104)$ & 2.3 & 69.7 \\
\hline Capitella capitata & $229(128)$ & 1.9 & 71.6 \\
\hline Maldane sarsi & $194(45)$ & 1.6 & 73.2 \\
\hline Levinsenia gracilis & $170(33)$ & 1.4 & 74.6 \\
\hline Total: & & & 74.6 \\
\hline \multicolumn{4}{|c|}{ (C) Non-seeps (GHM C, SR 2C, BR C) } \\
\hline Mendicula cf. pygmaea & $2125(343)$ & 30.5 & 30.5 \\
\hline Prionospio cirrifera & $408(107)$ & 5.9 & 36.4 \\
\hline Maldane sarsi & $396(33)$ & 5.7 & 42.1 \\
\hline Yoldiella solidula & $383(128)$ & 5.5 & 47.6 \\
\hline Nephasoma sp. & $356(206)$ & 5.1 & 52.7 \\
\hline Galathowenia oculata & $250(73)$ & 3.6 & 56.3 \\
\hline Spiochaetopterus typicus & $195(86)$ & 2.8 & 59.1 \\
\hline Spiophanes kroyeri & $177(8)$ & 2.5 & 61.6 \\
\hline Aphelochaeta sp. & $155(86)$ & 2.2 & 63.8 \\
\hline Heteromastus filiformis & $147(21)$ & 2.1 & 65.9 \\
\hline Total: & & & 65.9 \\
\hline
\end{tabular}

a $56.3 \%$ dissimilarity in faunal community composition. Three polychaete species, Spiochaetopterus typicus, $P$. cirrifera, and Galtathowenia ocuelata, explained most of this difference. This pattern was also observed on the CCA plot (Fig. 5), where stations in the Crater area formed a cluster aligned with high abundances of S. typicus, whereas Storfjord stations clustered along high abundances of P. cirrifera and G. ocuelata. A similar SIMPER comparison of faunal abundances between samples from Stns GHM 3, SR 1, and BR 3 (which included the strong seep influence samples) to the remaining stations and samples in the 'others' category showed a $64.5 \%$ overall dissimilarity. Here, the siboglinid polychaetes explained the largest difference in faunal community composition between these 2 groups $(10.2 \%)$.

In addition to the samples collected for the regional analysis (above), the ROV blade core at GHM 3 allowed for detailed characterization of the faunal composition inside one of the siboglinid worm fields located in the immediate vicinity of a methane gas flare at the GHMs (Tables $2 \& 3$ ). The blade core sample displayed by far the highest total faunal abundance (21833 ind. $\mathrm{m}^{-2}$ ) and biomass $\left(654 \mathrm{~g} \mathrm{ww} \mathrm{m}^{-2}\right.$ ) in this study (Table 2). The blade core contained high abundances of the chemosymbiotic siboglinids and $M$. cf. pygmaea bivalves, with densities of 7676 and 2500 ind. $\mathrm{m}^{-2}$, respectively. Overall, these 2 taxa alone contributed 35.1 and $11.5 \%$, respectively, to the total faunal abundance in the core (Table 3).
Crater area stations differed from Storfjord stations primarily in terms of environmental variables, such as depth and sediment characteristics. The outcome from statistical pairwise Pearson's correlation coefficients between selected environmental variables (TOC, grain size fraction, temperature, benthic pigments, porosity, salinity, and depth) and faunal parameters (abundance, biomass, $S$, and $J^{\prime}$ ) showed no significant correlations.

A SIMPER analysis on replicate faunal abundances between the clustered replicates (Fig. 4a) which separated the 2 regions (Storfjord and Crater area) showed

\subsection{Stable isotope composition $\left(\delta^{13} \mathrm{C}\right.$ and $\left.\delta^{15} \mathrm{~N}\right)$}

$\delta^{13} \mathrm{C}$ ratios among the studied taxa (Table 4 ) displayed a range of values between -16.2 and $-47.1 \%$. The highest (least negative) values were observed for the starfish Solaster endeca $(-16.2 \%)$, whilst the lowest values were observed for chemosymbiotic siboglinids $(-47.1 \%)$. The majority of the sampled Barents Sea organisms in this study displayed $\delta^{13} \mathrm{C}$ values in the range between -24 and $-16 \%$ (Table 4 , Fig. 6), suggesting a predominantly photosynthetic 

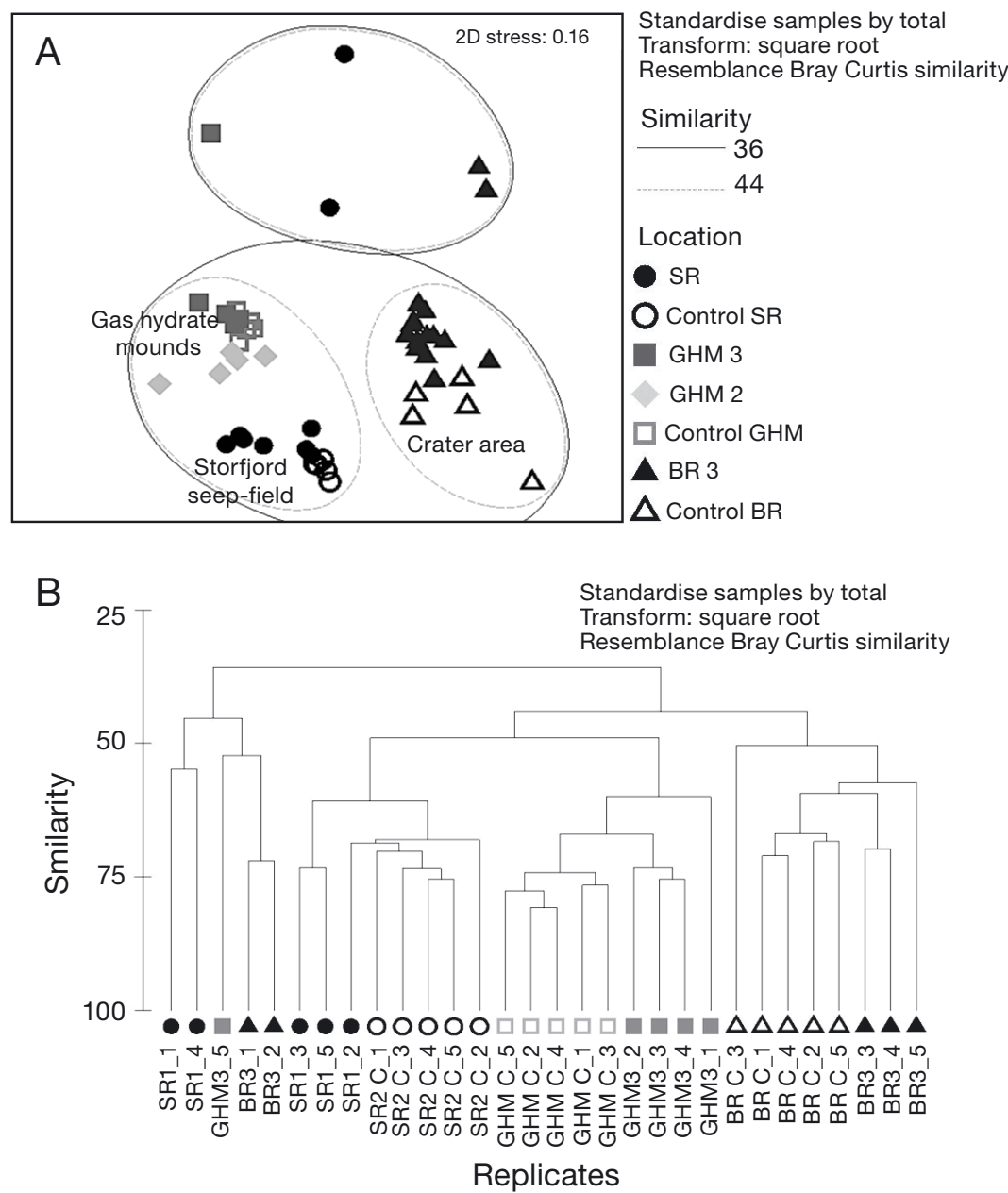

Fig. 4. Cluster analysis based on Bray-Curtis similarities of square-root transformed faunal abundances. (A) Non-metric multidimensional scaling plot calculated from all replicates. See Table 1 for detailed descriptions of locations. (B) Dendrogram representing the cluster analysis as per replicate sample, at Stns GHM 3, SR 1, and BR 3, and respective paired non-seep control replicates

source of carbon (Hobson \& Welch 1992, Søreide et al. 2006, 2008).

The food web baseline $\delta^{13} \mathrm{C}$-values of photosynthetically derived POM from the water column ranged from -27.3 to $-25.2 \%$, while $\mathrm{SOM}$, at sites without indication of microbial mats, reduced sediment patches, or free gas emissions, showed a baseline between -21.3 and $-20.5 \%$. A few sediment samples showed different $\delta^{13} \mathrm{C}$ values than the SOM baseline. For example, sediments collected with the ROV blade core underneath a filamentous bacterial mat exhibited a low $\delta^{13} \mathrm{C}$ signal $(-25.3 \%)$ compared to sediment collected at a non-seep reference control $(-20.5 \%)$ (Table 4). Despite the distinct (i.e. low) $\delta^{13} \mathrm{C}$-signature, sediment from the bacterial mat displayed $\delta^{15} \mathrm{~N}$ values that were not markedly different from other sediment samples $(4.3$ vs. $4.7 \%$, re- spectively). The lowest (most negative) $\delta^{13} \mathrm{C}$ and $\delta^{15} \mathrm{~N}$ signatures were recorded for dark-colored and reduced sediment patches $\left(\delta^{13} \mathrm{C}=-34.5 \%\right.$; $\delta^{15} \mathrm{~N}=3.3 \%$ o). Sediment samples collected from seeps without visual evidence of bacterial mats or reduced conditions displayed $\delta^{13} \mathrm{C}$ and $\delta^{15} \mathrm{~N}$ signals similar to the control non-seep samples $\left(\delta^{13} \mathrm{C}=-20.6\right.$ to $-20.9 \%$; $\delta^{15} \mathrm{~N}=4.4-4.6 \%$ ) .

The TL baseline, according to Eq. (1), was represented by $\delta^{15} \mathrm{~N}$ values from POM sources of $\sim 4 \%$ (Fig. 6, Table 4 ). Moving up the food web, first-order consumers of photosynthetically produced organic carbon (i.e. primarily grazers at $\mathrm{TL}=2.0$ ) were Onisimus sp. amphipods $\left(\delta^{13} \mathrm{C}=-21.5 \%, \delta^{15} \mathrm{~N}=\right.$ $7.5 \%$; TL $=2.0$ ), a gastropod, Hyalogyrina sp. $\left(\delta^{13} \mathrm{C}=-23.8 \%\right.$, $\delta^{15} \mathrm{~N}=8.3 \%$; $\mathrm{TL}=2.3$ ), and one unidentified species of krill (Euphasidae) $\left(\delta^{13} \mathrm{C}=-23.2 \%\right.$, $\delta^{15} \mathrm{~N}=8.9 \%$; TL $=2.4$ ) (Table 4). In addition, a few holothurians (e.g. Molpadia borealis) exhibited low $\delta^{15} \mathrm{~N}$ values that are typical for grazers, yet altogether, we observed a relatively wide range of $\delta^{15} \mathrm{~N}$ values among individual holothurians $\left(\delta^{15} \mathrm{~N}=5.8-11.3 \%\right.$; mean $\mathrm{TL}=2.7$ ). Most of the taxa in this survey can be considered $2^{\text {nd }}$ or $3^{\text {rd }}$ order benthic consumers at a TL $\sim 3-4$, i.e. typical deposit feeders/detrivores, predators, and/or scavengers. The starfish $S$. endeca $\left(\delta^{13} \mathrm{C}=-16.2 \%\right.$, $\delta^{15} \mathrm{~N}=14.2 \%$; $\mathrm{TL}=4.0)$ and the amphipod Epimeria loricata $\left(\delta^{13} \mathrm{C}=\right.$ $-19.8 \%$, $\delta^{15} \mathrm{~N}=14.4 \%$; TL $=4.1$ ) were the top predators we collected.

Siboglinid worms had distinctly low $\delta^{13} \mathrm{C}$ signatures $\left(\delta^{13} \mathrm{C}=-38.2\right.$, to $-47.1 \%$; Table 4 , Fig. 6$)$ in accordance with a chemosynthesis-based lifestyle. The siboglinid samples also exhibited the lowest $\delta^{15} \mathrm{~N}$ values among the secondary producers, ranging between -3.6 and $4.5 \%$.

Three different species of predatory/omnivorous and non-chemosymbiotic polychaetes exhibited relatively low $\delta^{13} \mathrm{C}$ values compared to the other heterotrophic organisms investigated in this survey (not including the chemosymbiotic siboglinids). Individuals of the carnivorous/omnivorous polychaetes Nephtys sp. and Scoletoma fragilis, as well as the deposit feeder Ophelina acuminata (Fauchald \& Jumars 


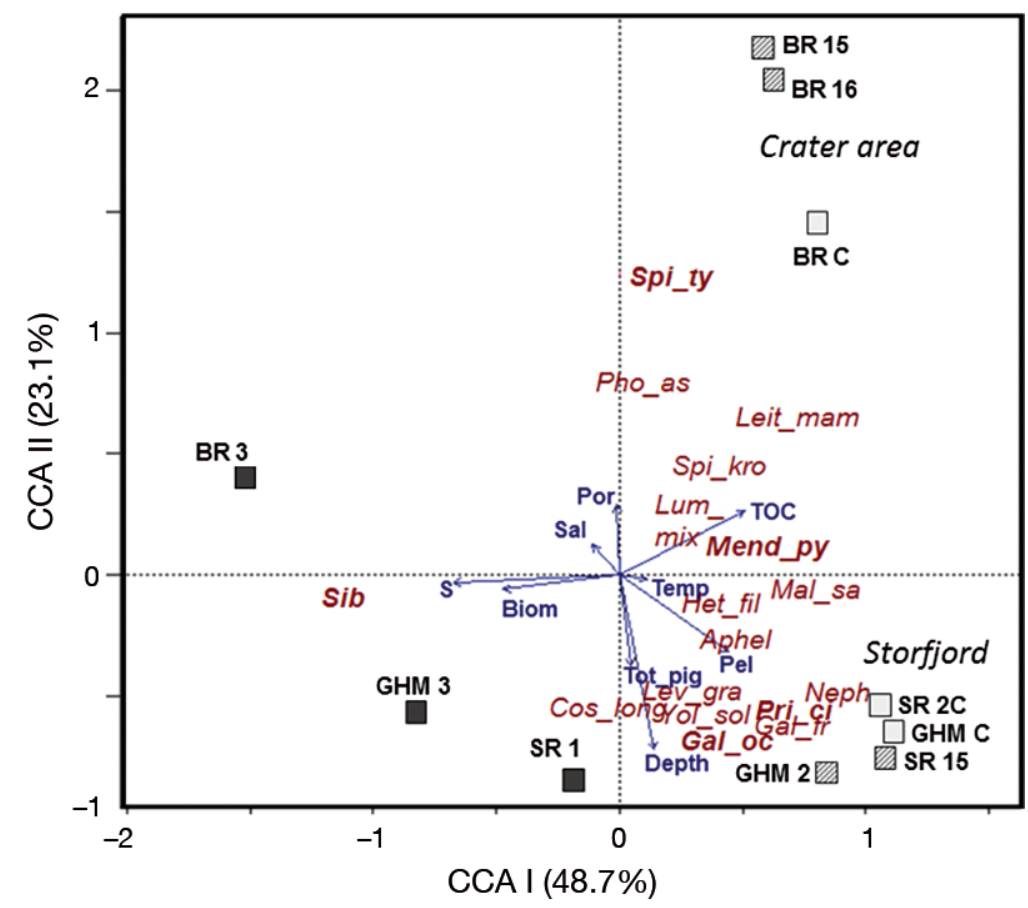

Fig. 5. Canonical correspondence analysis (CCA) based on station abundances of taxa contributing to more than $1 \%$ of the overall total faunal abundance in the survey, ordinated with standardized environmental variables: salinity, porosity, total benthic pigments, water depth, pelite fraction $(<0.63 \mu \mathrm{m})$, temperature, and total organic carbon in combination with aggregated station species richness and biomass. See Table 1 for detailed descriptions of station locations. Aphel: Aphelochaeta sp.; Cos_long: Cossura longocirrata; Gal_fra: Galathowenia fragilis; Gal_oc: Galathowenia oculata; Het_fil: Heteromastus filiformis; Leit_mam: Leitoscoloplos mammosus; Lev_ gra: Levinsenia gracilis; Lum_mix: Lumbrineris mixochaeta; Mal_sa: Maldane sarsi; Mend: Mendicula cf. pygmaea; Neph: Nephasoma sp.; Pho_ass: Pholoe assimilis; Sib: Siboglinidae (Frenulata); Spi_kro: Spiophanes kroyeri Spi_ty: Spiochaetopterus typicus; Yol_sol: Yoldiella solidula

1979, Cochrane et al. 2012) displayed $\delta^{13} \mathrm{C}$ values between -31.4 and $-26.1 \%$, and $\delta^{15} \mathrm{~N}$ values between 8.7 and $11.6 \%$. We also observed a large intraspecies variability in the $\delta^{13} \mathrm{C}$ signatures among these taxa. Individual samples of nephtyids collected within the same location (BR) exhibited a range of almost $15 \%$ between extremes $\left(\delta^{13} \mathrm{C}=-31.8\right.$ vs. $-17.0 \%$ ). Similarly, nephtyids from SR as well as the lumbrinerid $S$. fragilis collected from the GHM seeps exhibited large intra-species differences of up to $\sim 10 \%$ o (e.g. $\delta^{13} \mathrm{C}=-25.5$ vs. $-16.8 \%$ for nephtyids; $\delta^{13} \mathrm{C}=-29.1$ vs. $-18.9 \%$ for $S$. fragilis) between extreme samples. Among the other taxa, no such large variations were observed. Only the deposit feeding starfish Ctenodiscus crispatus displayed a somewhat elevated variability in its isotopic composition $\left(\delta^{13} \mathrm{C}=\right.$ -22.4 vs. $-16.6 \%$ ).

The results from the 2-component mixing calculations using $\mathrm{C}_{\mathrm{POM}}$ and $\mathrm{C}_{\mathrm{CBC}}$ as end-members for photosynthetic vs. chemosynthetic (here defined as biosynthesis based on methane) primary production sources at the cold seeps indicated that tissues from some invertebrates (not only chemosymbiotic siboglinids) reflected carbon from chemical energy sources to varying degrees. We found individuals among the nephtyids, lumbrinerids, and $O$. acuminata with comparatively low $\delta^{13} \mathrm{C}$ signatures. Furthermore, the calculated fraction of incorporated $\mathrm{CBC}$ varied between 1.8 and $28.7 \%$ of their total carbon intake (Table 4). Using the higher $\delta^{13} \mathrm{C}$ based on SOM instead of POM (i.e. -20.7 vs. $-25.1 \%$ ) as a primary photosynthetic carbon source signature for the end-member calculations yields an even larger contribution of CBC for these polychaetes (18.3-40.7\%). Moreover, when we applied $\delta^{13} \mathrm{C}_{\mathrm{SOM}}$ as the photosynthetic end-member source, the carbon isotope balance calculations indicated that several other taxa, in addition to the siboglinids and the abovementioned heterotrophic polychaetes, incorporate chemosynthesized carbon to some extent (between 1.1 and $11.8 \%$; Table 4$)$. For the alternative approaches including $\mathrm{SOB}\left(\delta^{13} \mathrm{C}=\right.$ $-35 \%$ ) and the low carbon isotope signature for methane-derived carbon $\left(\delta^{13} \mathrm{C}=\right.$ $-85 \%$ ) in the 2-component mixing model respectively, we calculated a maximum contribution of $\mathrm{CBC}$ ranging between 10.5 and $74.8 \%$ to the heterotrophic benthic community (Table S1, Fig. S1).

\section{DISCUSSION}

We found high benthic biomass and high faunal abundances at seep sites, despite large intra-station variability. ROV-guided benthic sampling among chemosymbiotic worm tufts within the seeps additionally revealed high population density of macroorganisms, including high overall abundances of chemosymbiotic siboglinid worms and Mendicula cf. pygmaea bivalves. We documented a complex and variable benthic seascape at seeps where habitat heterogeneity was elevated across multiple spatial scales by the presence of both biological and geological seep-associated features (microbial mats, tufts of chemosymbiotic tubeworms, and methane-derived 
Table 4. Mean $( \pm \mathrm{SD}) \delta^{13} \mathrm{C}$ and $\delta^{15} \mathrm{~N}$ of benthic organisms at the study sites (see Table 1 for location abbreviations in the 'Sample' column). n: number of individual samples; TL: calculated trophic level; F: potential contribution of chemosynthetically derived carbon in relation to photosynthetic carbon sources from particulate organic matter (POM) or sedimentary organic matter (SOM) using the methane end-member $\left(\mathrm{C}_{\mathrm{CH} 4}-47 \%\right.$ o). N/A: not applicable

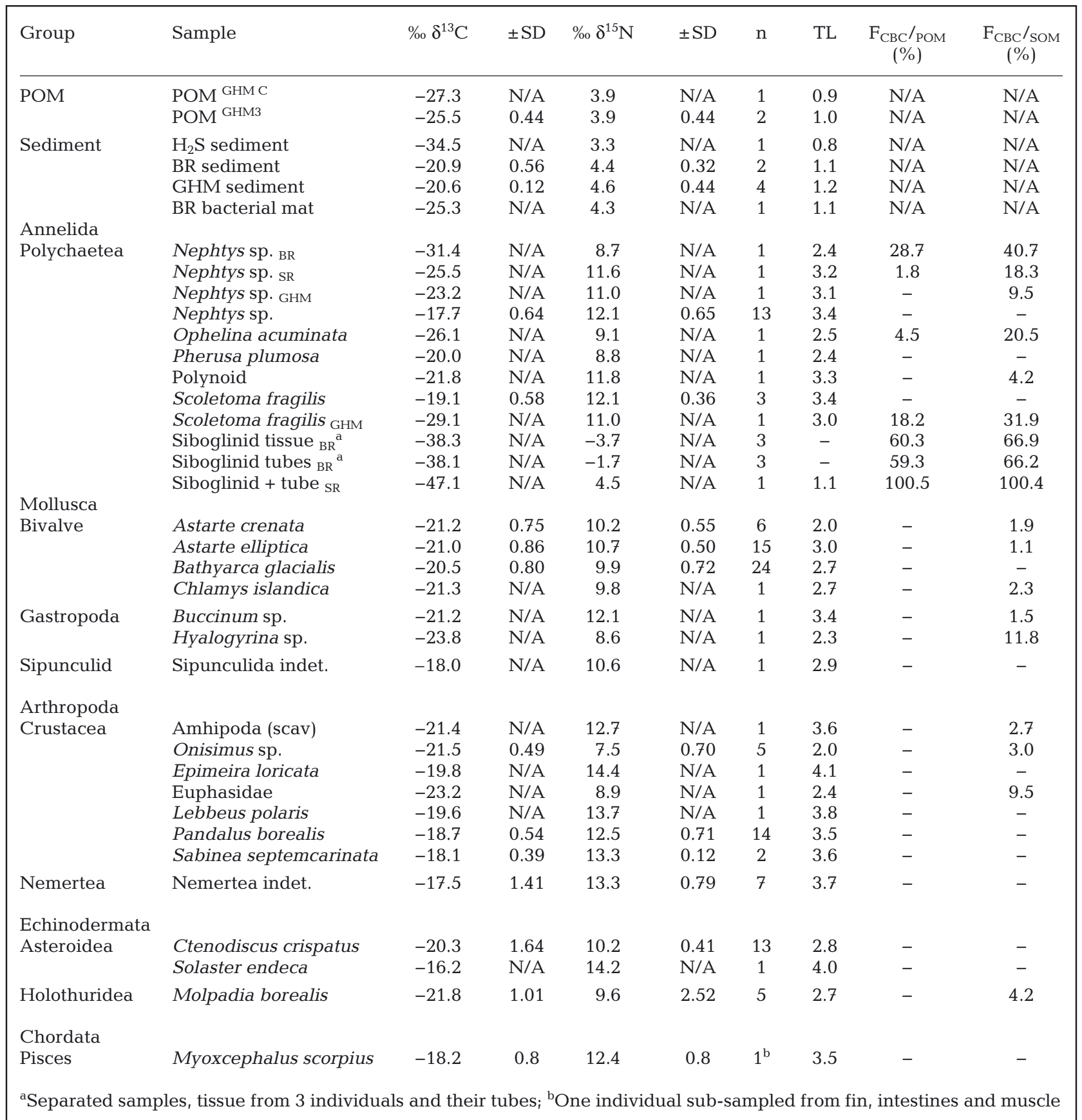

authigneic carbonates), which we suggest leads to macro- and megafauna as well as smaller organisms aggregating around the seeps (Figs. $3 \& 7$ ).

Furthermore, we demonstrated that carbon derived from chemical energy sources originating from seeping methane in the Barents Sea is incorporated into the macrofaunal food web. We found 3 different species of heterotrophic worms from active cold seeps that possess low $\delta^{13} \mathrm{C}$ signatures in comparison to other individuals within the same taxa from this study (Table 4). The low $\delta^{13} \mathrm{C}$ signatures indicate that chemosynthetic carbon contributes up to $40.7 \%$ to 


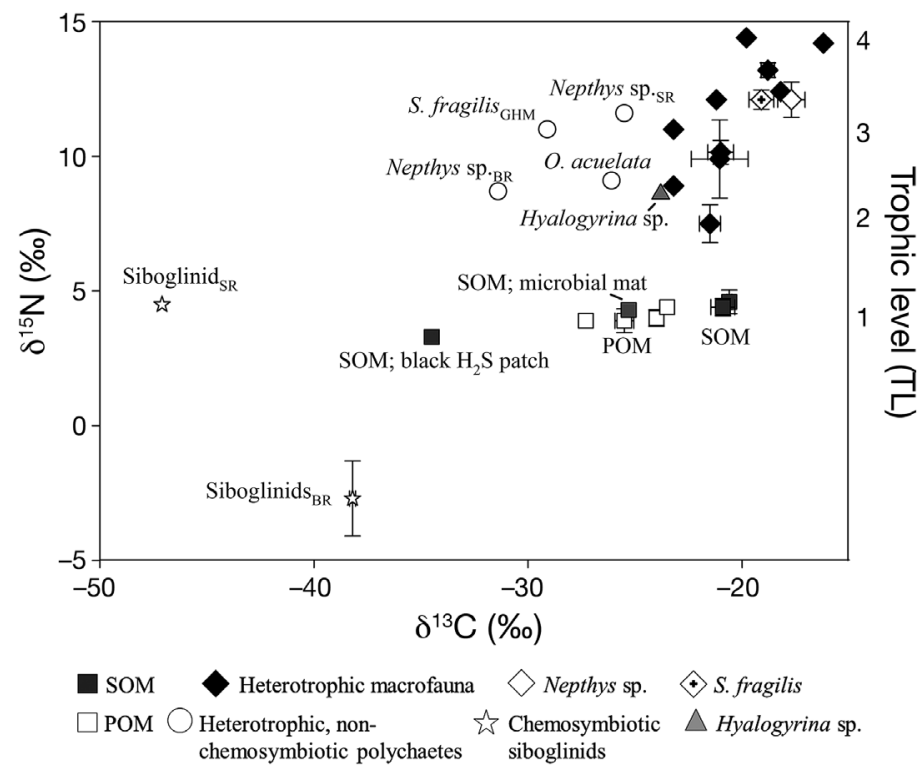

Fig. 6. Simplified bi-plot of $\delta^{13} \mathrm{C}$ and $\delta^{14} \mathrm{~N}$ values of selected organisms as well as sediment and particulate organic matter (SOM and POM) in the Barents Sea. Vertical and horizontal error bars: $\pm \mathrm{SD}$. Vertical axis to the right indicates calculated trophic levels from Table 4

their diet. These results highlight the incorporation of $\mathrm{CBC}$ in heterotrophic, non-chemosymbiotic taxa, complementing the photosynthetic carbon sources generally used by these benthic organisms (e.g. Decker \& Olu 2012, Zapata-Hernández et al. 2014).

\subsection{Cold seep community structure and regional differences}

Our results show that chemosymbiotic siboglinids represent key organisms and are highly abundant at cold seeps in the Barents Sea together with the thyasirid bivalve $M$. cf. pygmaea. Siboglinids dominated the species abundance at the methane seep sites. The mean density of GHM worm tufts was $\sim 7000 \mathrm{~m}^{-2}$ and where they mass-occurred forming tuft-aggregations, they contributed the most to the total polychaete biomass. Overall, we noted a tendency towards higher faunal abundance (up to $\sim 1.5-2.5 \times$ higher) and biomass ( 2.5-3.5× higher) at seep stations compared to the control non-seep stations (Table 2). Yet the relationship was not statistically significant because of the high variability among the replicates and stations.

We observed a considerably higher total benthic abundance (mean $=7936$ vs. 4340 ind. $\mathrm{m}^{-2}$ ) and biomass (147.0 vs. $65.5 \mathrm{~g} \mathrm{ww} \mathrm{m}^{-2}$ ) in this study com- pared to nearby Barents Sea stations at similar depths in areas without seafloor methane seepage, as investigated by Carroll et al. (2008) using identical sampling procedures. At Stn GHM 3, a particularly high faunal abundance and biomass was observed, not only with respect to individual stations without seepage in the Barents Sea (Carroll et al. 2008, Cochrane et al. 2012), but also in comparison to much shallower stations (including seep sites) on the western Svalbard shelf (Åström et al. 2016). The single blade core replicate at GHM $3_{\mathrm{bl}}$ (Tables $1 \& 2$ ) from one of the siboglinid worm tufts displayed by far the highest faunal abundance (21833 ind. $\mathrm{m}^{-2}$ ) and biomass $\left(654 \mathrm{~g} \mathrm{ww} \mathrm{m}^{-2}\right)$. This sample would have been difficult to obtain without the video-guided ROV system used here, which provided a unique view into the macroinfaunal community in the tuft where the top 3 most abundant species account for more than $50 \%$ of the total abundance (Table 3). Similarly, at 3 grab stations (GHM 3, SR 1, and BR 3), siboglinids and $M$. cf. pygmaea bivalves dominated the faunal abundance (43.7 and $12.5 \%$, respectively) and these 2 species contributed to over $50 \%$ of the total faunal abundances at these stations (Table 3). Moreover, M. cf. pygmaea bivalves were also prominent at the control non-seepage stations, with average density of 2125 ind. $\mathrm{m}^{-2}$, contributing to $30.5 \%$ of the total faunal abundance at these reference sites.

The small (mm-sized) thyasirid bivalve $M$. cf. pygmaea was the most abundant taxa across all stations. It was abundant both at cold seeps and non-seep control stations. In general, thyasirids are known to be abundant in highly reduced habitats, such as seep habitats and organic-rich sediments (Taylor \& Glover 2010); however, the high abundances of $M$. cf. pygmaea across all stations in this study is not readily explained. Low $\delta^{13} \mathrm{C}$ signature in bivalve tissue has been recognized for many thyasirid species (Dando \& Spiro 1993, Dufour 2005), suggesting uptake of CBC. Yet this does not necessarily imply a fully chemosymbiotic lifestyle for all species, as Family Thyasiridae includes species with a wide range of different dietary adaptations, from microbial syntrophy and chemosymbiosis to mixotrophy and heterotrophy (Dando \& Spiro 1993, Dufour 2005, Taylor \& Glover 2010). To date, there are no studies that provide direct evidence that $M$. cf. pygmaea is associated with chemosymbionts for nutritional dependence (Oliver \& Killeen 2002, Dufour 2005, Taylor \& Glover 2010). We were unfortunately unable to analyze $M$. cf. pygmaea tissues specifically for $\delta^{13} \mathrm{C}$ and $\delta^{15} \mathrm{~N}$, despite their high abundances. The samples in which $M$. cf. pygmaea were found were contaminated with 
formaldehyde and buffering reagents as they were assigned for community analysis before species identification was undertaken. Thus, we can only speculate as to whether these thyasirids were able to incorporate chemosynthesized carbon and use CBC as an energy source (Oliver \& Killeen 2002, Dufour 2005). The marked association of high abundances of $M$. cf. pygmaea with the seeps suggests, however, that they may also benefit directly or indirectly from the reduced seep habitat, similar to many other thyasirid species.

The nMDS plot and cluster analysis (Fig. 4a,b) revealed high variability in faunal community structure at the seeps over relatively small spatial scales (i.e. grab samples). Moreover, variability in community structure and environmental conditions were observed between stations over larger scales (regionally) in the CCA (Fig. 5). Our observations support the pattern that cold seeps are commonly characterized by high macrofaunal abundances and biomass (Gebruk et al. 2003, Bowden et al. 2013, Sen et al. 2018a) and are inhabited by distinct faunal communities (Sibuet \& Olu 1998, Bergquist et al. 2005, Levin 2005). In the Bray-Curtis similarity analysis and the nMDS plot (Fig. 4a), 5 individual replicates were significantly different with respect to community structure when compared to the rest of the samples in this study, regardless of where they were sampled (SR, $\mathrm{BR}$, or GHM). The other peripheral seep samples (not including the abovementioned 5 replicates) clustered with the paired controls (non-seep stations and replicates), and were clearly separated ( $44 \%$ similarity) by region (i.e. Storfjord or Crater area) (Fig. 4a). These regional differences in overall faunal community structure were driven mostly by variations in abundance among the taxa Spiochaetopterus typicus (Crater area) and Prionospio cirrifera and Galathowenia oculata (Storfjord), as tested by SIMPER. These results demonstrate that the typical faunal characteristics that appear to be intrinsic to stations with a strong seep influence override the regionally constrained faunal characteristics within the Barents Sea. The seep-specific faunal characteristics, however, are not pervasive enough to override largerscale oceanographic regional differences in the faunal community between the West Svalbard shelf and the Barents Sea, as demonstrated in Åström et al. (2016). Moreover, the CCA analysis supports these findings and observed patterns (Fig. 5). It highlights 3 stations (GHM 3, BR 3, and SR 1) that are distinct from the rest along the $x$-axis (CCA I), regardless of region. The rest of the stations clustered together based on region (as either Storfjord or Crater area), and diverged along the $y$-axis (CCA II). Storfjord stations are influenced to a larger extent by relatively high concentrations of sediment-bound chlorophyll pigments and water column depth (Fig. 5), a somewhat counterintuitive result since sediment pigment concentrations are expected to decrease with depth (Gage \& Tyler 1991, Renaud et al. 2008). We explain this pattern by the location of the 2 main regions and the relatively small differences in depth (Storfjord: 350-380 mi Crater area: $330 \mathrm{~m}$ ) (Loeng 1991). Stations at the Crater area, located in the central Barents Sea, are less influenced by the North Atlantic Current (NAC) regime, and are more distant from coastline and nutrient fluvial transport from land which could result in less pronounced surface productivity, offsetting a systematic depth-to-chl a concentration relationship between these stations.

The separation of the 3 disconnected stations (GHM 3, BR 3, and SR 1 ) along the $x$-axis was mainly driven by differences in $S$, biomass, abundance of the siboglinids, and, to a lesser extent, temperature. Even though this analysis was based on composite stations reflecting a broader spatial scale, it further confirms that the ecological impacts of gas seepage seem to override regional difference.

In summary, our comparative analysis, both with regards to individual samples (Fig. 4a,b) and among stations (Fig. 5), underlines that the characteristic benthic community shaped by the influence from seafloor seepage overrides faunal and biogeographical aspects within the Barents Sea. This implies that strong seep-influenced samples collected at cold seeps more than $300 \mathrm{~km}$ away from each other are more similar with regards to community characteristics than seep samples categorized as peripheral, collected just a few meters away. Such similarities, however, are not shared between Western Svalbard and the Barents Sea where, as documented in Åström et al. (2016), regional large-scale oceanographic differences override benthic community patterns at the cold seeps.

\subsection{Seep-associated food webs: carbon sources and trophic structure}

The lowest $\delta^{13} \mathrm{C}$ signatures in this study (-38.3 and $-47.1 \%$ ) were recorded for chemosymbiotic worms (frenulate siboglinids). These values are between 20 and $30 \%$ lighter than the $\delta^{13} \mathrm{C}$ composition of other organisms tested in this study, which likely rely mainly on POM/SOM carbon sources. Siboglinids represent a family of polychaetes commonly associ- 
ated with hydrothermal vents, cold seeps, organic falls, or other reduced habitats. Adult siboglinids (Frenulata) lack a digestive tract and obtain most of their nutrition from thiotrophy or methanotrophy through endosymbiotic bacteria housed in a specialized organ called the trophosome (Southward et al. 1986, Schmaljohann et al. 1990, Rodrigues et al. 2011). Our stable isotope measurements clearly reflect this symbiotic lifestyle (Table 4, Fig. 6) (Southward et al. 1986).

With respect to Arctic siboglinids, published $\delta^{13} \mathrm{C}$ signatures from Oligobrachia frenulates suggest the involvement of methanotrophic symbionts because of the characteristically low $\delta^{13} \mathrm{C}$ signatures observed among them ( -50 to $-62 \%$; Gebruk et al. 2003, Decker \& Olu 2012, Paull et al. 2015). Furthermore, Savvichev et al. (2018) observed methanotrophs in Oligobrachia frenualtes from the Laptev Sea in transmission electron microscope (TEM) images. Other studies targeting the symbionts of these animals were, however, more equivocal. Unlike Savvichev et al. (2018), Lösekann et al. (2008) and Sen et al. (2018b) only observed SOB in TEM images of Oligobrachia haakonmosbiensis from HMMV, and in Oligobrachia sp. CPL-clade from GHM and the Crater area, respectively. Additionally, they were unable to amplify sequences for enzymes associated with methane oxidation, although they were able to amplify sequences associated with sulfur oxidation. In both these studies and species, bacterial 16S rRNA sequencing from trophosome tissue revealed the presence of a group of bacteria whose relationship to sulfur- and methaneoxidizing symbionts could not be determined but whose closest cultivated relative is a facultative sulfur oxidizer (Lösekann et al. 2008, Sen et al. 2018b). The reason for such an apparent discrepancy between indirect evidence by isotopic signatures and observable endosymbionts could be related to the worms' uptake of DIC that is ultimately derived from AOM. The DIC at these seeps display a ${ }^{13} \mathrm{C}$-depleted signature and its uptake could account for the lower $\delta^{13} \mathrm{C}$ signature of worm tissue than would be expected from a sulfidebased lifestyle (Lösekann et al. 2008). Indeed, Sen et al. (2019) found that $O$. haakonmosbiensis worms from a North Atlantic seep-site (Lofoten) displayed $\delta^{13} \mathrm{C}$ signatures that were similar to those of carbonate outcrops around them, suggesting that worms and carbonates alike build in ${ }^{13} \mathrm{C}$-depleted inorganic carbon from the same sedimentary carbon pool. Frenulates are also known to supplement their symbiontderived nutrition with uptake of sediment organic molecules (Dando et al. 2008). If organic carbon in the sediment at these seep sites is already ${ }^{13} \mathrm{C}$-depleted, their uptake could serve as an additional potential explanation for the low $\delta^{13} \mathrm{C}$ values observed among Oligobrachia frenulates (Lösekann et al. 2008).

Interestingly, the bulk $\delta^{13} \mathrm{C}$ signatures we observed in this study were higher than all previously published values for frenulate siboglinids (Oligobrachia spp.) from high-latitude seeps: we measured $-38.3 \%$ at $\mathrm{BR}$ and $-47.1 \%$ at $\mathrm{SR}$, in comparison to -51.1 to $-56.1 \%$ measured at HMMV (Gebruk et al. 2003), $-62.1 \%$ from the Storegga seeps (Decker \& Olu 2012), $-52.1 \%$ at the North Atlantic Lofoten seep site (Sen et al. 2019), and $-55.0 \%$ in the Beaufort Sea (Paull et al. 2015). The carbon isotopic differences may be species-related or may be due to different environmental conditions and sedimentological regimes, or both. O. haakonmosbiensis has been identified as the frenulate species being present at both HMMV and the Lofoten seep-site (Lösekann et al. 2008, Sen et al. 2019). From frenulates sampled in the Beaufort Sea, Paull et al. (2015) reported $97 \%$ similarity with $O$. haakonmosbiensis based on cytochrome $C$ oxidase subunit I (COI) mitochondrial DNA sequences, and Decker \& Olu (2012) described the frenulates at Storegga seeps as O. cf. haakonmosbiensis. Sen et al. (2018b) described a cryptic Oligobrachia species (CPL-clade) occurring in the Barents Sea and the Laptev Sea. We could not identify siboglinids (frenulates) collected in this study to species level; however, Oligobrachia was also observed (Fig. 3B), likely belonging to the Oligobrachia sp. CPL-clade (Sen et al. 2018b). Therefore, the differences between values we obtained in this study and those published in other studies could be due to different species being targeted. This itself suggests that Oligobrachia species might differ in their symbiotic partnerships and endobacterial populations or consortia: differing extents of reliance on one type of reduced chemical versus another could lead to varying carbon isotopic signatures across different species (Rodrigues et al. 2011, Sen et al. 2018b). Alternatively, if sediment DIC and organic matter uptake strongly influences the carbon isotopic signature of Arctic seep siboglinids, as discussed above, another explanation for the marked difference between our and previous isotopic results could be that different environmental/sedimentological conditions exists, and that different inorganic carbon sources are prevalent at these high-latitude seeps. Such variability would almost certainly manifest itself in diverse carbon isotope compositions in resident Oligobrachia worms. Indeed, the differences we observed between the BR and SR regions, which supposedly host the same Oligobrachia species (Sen et al. 2018b), suggests that 
local environmental conditions might constrain the carbon isotopic signatures of Arctic seep Oligobrachia worms. Taken together, these results and observations highlight the paucity of studies and lack of knowledge with regards to the species composition and ecology of high-latitude siboglinids.

While hosting microbial endosymbionts is a strategy that makes direct use of reduced substances in seep-associated sediments, another strategy employed by seep organisms relies on benefitting indirectly from chemosynthetic food production through microbial grazing. This feeding strategy has been observed at hydrothermal vents, cold seeps, and whale falls, and is typically performed by organisms such as gastropods, crustaceans, and polychaetes (e.g. Van Dover \& Fry 1989, Braby et al. 2007, Niemann et al. 2013). In a ROV core sample from the Crater area, a number of mm-sized gastropods identified as Hyalogyrina sp. (A. Warén pers. comm.) were recovered from microbial mats (Fig. 7G). The Hyalogyrina genus has been observed at vents, cold seeps, and other reducing habitats where they are usually associated with microbial mats (Braby et al. 2007, Guillon et al. 2017). Their high densities among microbial mats suggest that Hyalogyrina gastropods are microbial grazers, which has been reported from other seeps (Guillon et al. 2017). The Hyalogyrina from our analysis displayed signatures of $\delta^{13} \mathrm{C}=-23.8 \%$ and $\delta^{15} \mathrm{~N}=8.6 \%$. This $\delta^{13} \mathrm{C}$ value is relatively high in comparison with other suggested microbe-grazing gastropods, for example rissoids from the HMMV which displayed $\delta^{13} \mathrm{C}$ values as low as $-46.6 \%$ in microbial mats and $-40.2 \%$ in the adjacent sediment (Decker \& Olu 2012). Our reported $\delta^{13} \mathrm{C}$ and $\delta^{15} \mathrm{~N}$ values for Hyalogyrina, in relation to the signatures from the sediment where it was found $\left(\delta^{13} \mathrm{C}=\right.$ $-25.3 \%$ and $\delta^{15} \mathrm{~N}=4.3 \%$; Table 4 ) and its calculated TL of 2.3, however, suggest that Hyalogyrina is a first-order consumer that is likely grazing the sediments around the microbial mats. Furthermore, the output from the end-member mixing calculation (Eq. 2) revealed partial input of CBC to Hyalogyrina gastropods (4.8-21.7\%; Tables $4 \& \mathrm{~S} 1)$. These results, along with our ROV observations of Hyalogyrina aggregations in the reduced sediment and at the microbial mats, suggest that the gastropods partly carry out microbial grazing.

A few predatory polychaetes exhibited large intraspecies variability with regards to the putative assimilated carbon sources (Fig. 6, Table 4). The observed range of $\delta^{13} \mathrm{C}$ values for Nephtys sp. was -16.8 to $-31.4 \%$, and that of Scoletoma fragilis similarly varied between -18.6 and $-29.1 \%$. These stable isotope signatures suggest a large niche width and/or an opportunistic diet. Furthermore, the signatures suggest that the polychaetes have a wide range of preferred prey with variable $\delta^{13} \mathrm{C}$ signatures, feeding partly upon organisms that directly assimilate CBC. Alternatively, the predatory polychaetes prey on organisms that use carbon that has been originally produced chemolithotrophically and shunted between organisms within the benthic food web. Our results from the end-member mixing calculation (Eq. 2), assuming input sources of POM $(-25.1 \%)$ and $\mathrm{CBC}$ (based on methane $\delta^{13} \mathrm{C}=-47.0 \%$ ), suggest that some polychaetes (i.e. polychaetes with the lowest $\delta^{13} \mathrm{C}$ ) derive up to nearly $30 \%$ of their carbon diet from chemical energy sources (total range between 1.8 and $28.7 \%$ ). Considering that none of these polychaetes are 'seep-endemic' (Bergquist et al. 2005, Levin et al. 2016) or known to form symbiotic associations with microbes that can utilize methane or sulfide, such an input of $\mathrm{CBC}$ is somewhat surprising, although still realistic considering the lifestyle of these worms (i.e. motile predators and omnivorous feeders). Further studies are necessary to assess the modes by which they incorporate $\mathrm{CBC}$ in their diets: whether they prey on animals that are directly associated with microbial symbionts, consume prey that grazes on mats of methanotrophic/sulfide-oxidizing microbes, or whether their prey acquires a low $\delta^{13} \mathrm{C}$ isotope signature indirectly by incorporating chemosynthesized carbon that has been recycled within the microbial loop. Our estimates of the contribution of chemosynthesized carbon originating from cold seeps vs. photosynthetically derived carbon from the water column (i.e. POM) must be considered conservative. SOM (with a higher $\delta^{13} \mathrm{C}$ than POM) is probably the most utilized photosynthetic carbon source for shelf benthos. Using SOM as the photosynthetic end-member in the model yields contributions of $18.3-40.7 \%$ of $\mathrm{CBC}$ into these non-chemosymbiotic polychaetes (Table 4 ).

In a first attempt to more quantitatively assess the incorporation of seep-derived carbon (i.e. $\mathrm{CBC}$ ) into the benthic community, we used the isotopic signature of methane from the GHM site $\left(\delta^{13} \mathrm{C}=-47.0 \%\right.$ o) as the primary end-member for $\delta^{13} \mathrm{C}$ balance calculations (Table 4). By alternatively using end-member $\delta^{13} \mathrm{C}$ values for SOB $(-35 \%)$ and fractionated AOM sources $(-85 \%)$, we take into account the whole potential range of different carbon substrates and acknowledge the uncertainty of the true end-member $\delta^{13} \mathrm{C}$, leading to a broader range of estimates on the incorporation of $\mathrm{CBC}$ to the heterotrophic taxa between 10.5 and $74.8 \%$ for the most extreme samples 

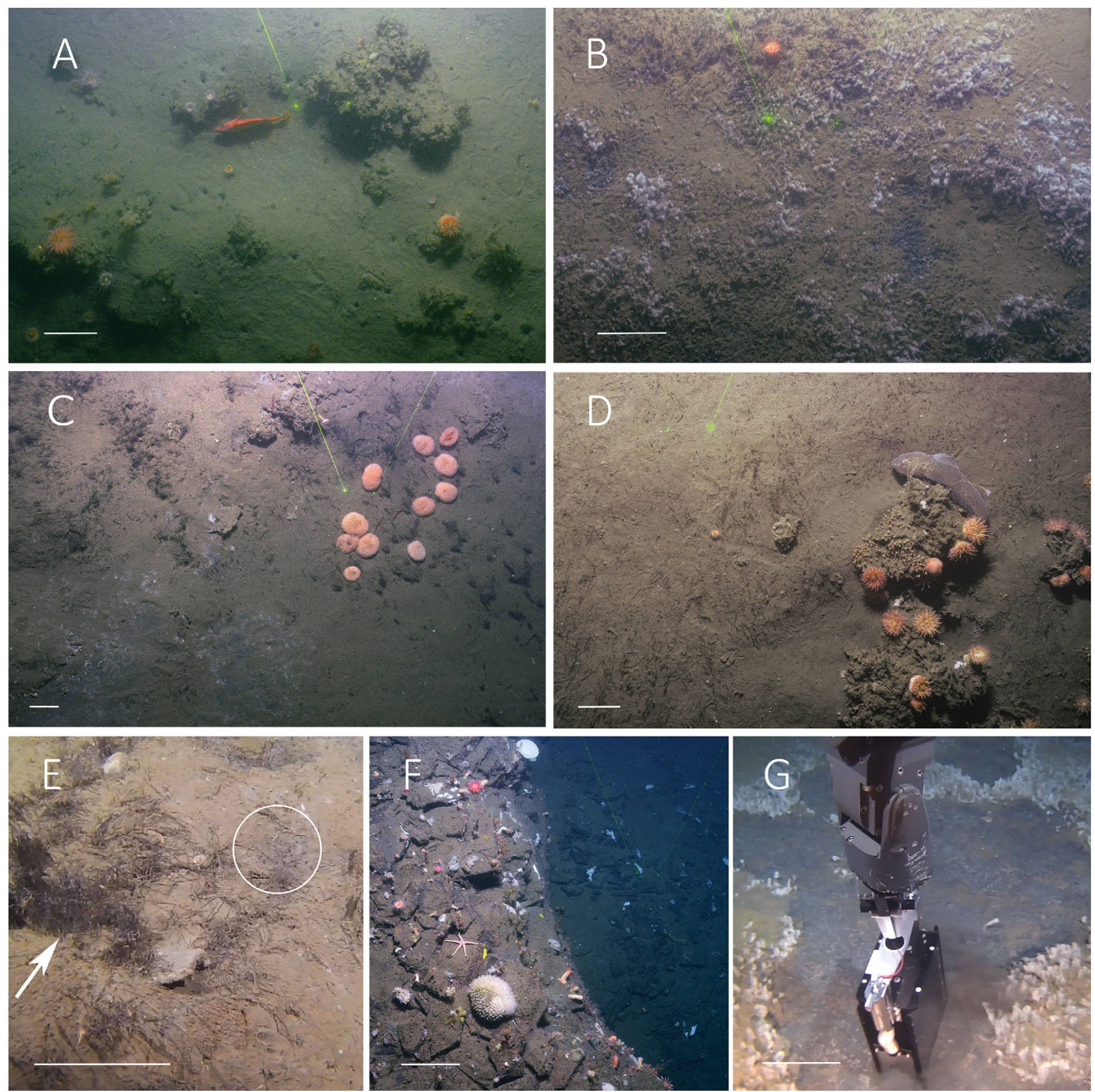

Fig. 7. Representative photographs of seep habitats at cold seeps in the Barents Sea. (A) Storfjordrenna seep field: carbonate outcrops with hard bottom anemones and a red rockfish (Sebastus sp.). (B) Dense mat of chemosymbiotic frenulate worms colonized by filamentous bacteria. (C) Gas hydrate mound (GHM) seeps: pom-pom anemones (Liponema sp.) and shrimps (Pandalus borealis) in a frenulate worm tuft. (D) A spotted wolf fish Anarhichas minor next to carbonate rocks colonized by anemones, solitary corals, and hydrozoans. (E) Close-up of a frenulate worm tuft at the GHM seeps (white arrow); lighter colored sediment to the right (circle) indicates patches of microbial mats. (F) Crater area: rock slabs and hard surfaces on a slope into one of the craters colonized by various epifauna (sponges, starfishes, and anemones). (G) Remotely operated vehicle sampling in a patch of a microbial mat surrounded by a field of frenulate worms partially covered with filamentous bacteria. Hyalogyrina sp. snails were recovered from the mat. Scale bar: $20 \mathrm{~cm}$

(Table S1). Our analysis revealed that taxa with low $\delta^{13} \mathrm{C}$ values partially incorporate $\mathrm{CBC}$ regardless of the modeled scenarios using different end-member carbon sources (Tables 4 \& S1).
Our stable isotope analyses overlapped only partially with all taxa included in the community structure analysis. We did not sample smaller macroorganisms or meiofauna and we examined the stable 
isotopic composition only for a few first-order consumers, top predators, and vertebrates. Potential intermediate food chain links between the obligate chemosymbiotic siboglinids, chemoautotrophic consumers, and associated organisms occupying the worm tufts may therefore have been overlooked in the constructed food web (Figs. 6 \& S1, Tables 4 \& S1). Nevertheless, all our results support the conclusion that $\mathrm{CBC}$ originating from seeps contributes to the nutrition of the Barents Sea cold seep fauna over a whole range of taxonomic groups, and well beyond the chemosymbiotic siboglinids.

\subsection{Cold seep heterogeneity: habitat variability for benthic fauna}

The cold seeps we investigated displayed high abundance and biomass compared to habitats in the Barents Sea where cold seeps are absent (Carroll et al. 2008, Cochrane et al. 2012). Furthermore, the seeps in this study (SR, GHM, and BR) displayed a high degree of within-station seafloor heterogeneity (Fig. 7), both in terms of biological and geological/ structural features. Seafloor methane seepage is typically associated with strong biogeochemical gradients (Gebruk et al. 2003, Bergquist et al. 2005, Sen et al. 2018a) in the sediment which leads to small-scale habitat heterogeneity, for example by creating carbonate precipitate layers, and supporting microbial mats and aggregations of chemosymbiotic fauna. ROV and photo transects conducted over Storfjord and Crater area seeps revealed mosaics with distinct patches of microbial mats and tufts of siboglinids (Fig. 7). Such localized zonation patterns have also been recognized at other cold seeps (Bergquist et al. 2005, Decker \& Olu 2012, Bowden et al. 2013) and once more underscore the importance of 'visual' sampling (i.e. ROV or cameraguided grabs and cores). Using such combinations of equipment and visual tools at the seeps will certainly lead to a better ecological understanding of the communities at these multifaceted habitats (Jørgensen et al. 2011, Bicknell et al. 2016). Our observations of worm tufts forming distinct zones on the seabed is likely controlled by the siboglinids' preference for a habitat with access to optimal sulfide concentrations and/or sulfide fluxes (Sahling et al. 2003, Dando et al. 2008, Sen et al. 2018a). Siboglinids (Frenulata) are thin $(<1 \mathrm{~mm}$ in diameter), although they can reach considerable length (50$60 \mathrm{~cm}$ ) and build chitinous tubes that extend several $10 \mathrm{~s}$ of $\mathrm{cm}$ into the sediment. These tubes protrude a few $\mathrm{cm}$ from the seabed, creating mats or tuft-like structures on the seafloor (Fig. $7 \mathrm{~B}, \mathrm{E}$ ), and in this way, the worm tufts add small-scale 3D heterogeneity to the seep habitat. Within tuft samples, we found many small benthic organisms using the tubes as substrate (e.g. caprellid amphipods, mollusks, and polychaetes) and ROV video images revealed aggregations of shrimps and amphipods within the worm tufts. Moreover, several siboglinid tubes were covered with epibenthic foraminifera (e.g. Cibicidoides) and overgrown by filamentous bacteria, patterns that are known from other seeps (Levin 2005, Sen et al. 2018b) (Figs. 3 \& 7B,G). Even though siboglinids within the clade Frenulata are small in comparison to other siboglinids (Vestamentifera) inhabiting seeps, such as Lamellibrachia and Escarpia, they function as important ecosystem engineers, providing substrate and resources for micro- and meiobenthos, as observed in this study. They are also likely to influence the seabed geochemistry by enhancing the turnover rates of biogeochemical processes through the uptake and release of oxygen, sulfide, and other compounds in the sediment and overlying water (Freytag et al. 2001, Dando et al. 2008, Sen et al. 2019).

In addition to the small benthic invertebrates utilizing the substrate of the worm tubes, we observed larger megafauna such as pycnogonids, amphipods, and gastropods, as well as various fishes aggregating around these tufts. In ROV videos and tow-camera images from the 3 cold seep locations (SR, GHM, and $\mathrm{BR})$, abundant megafauna appeared in close vicinity to siboglinid worm-tufts, microbial mats, and/or around the carbonate outcrops. Similar observations were documented in Åström et al. (2018) and Sen et al. (2018a), who reported increased biodiversity and high abundance of epifaunal megafauna around carbonate outcrops at Arctic cold seeps compared to adjacent areas without carbonate outcrops. The variability in the seafloor relief provided by carbonate outcrops and other hard surfaces at the seeps (Fig. $7 \mathrm{~A}, \mathrm{C}, \mathrm{D}, \mathrm{F}$ ) could lead to megafaunal accumulations similar to those observed at reefs or other complex seabed structures that can provide ample substrate and protection against predators in predominantly soft-bottom habitats (e.g. Jensen et al. 1992, Meyer et al. 2014). In conclusion, the nature of the multi-faceted and heterogeneous habitat at cold seeps allows organisms to exploit a multitude of niches within these habitats on various spatial scales, where carbonate rock formations and worm tufts provide 3D structure for meio-, macro-, and megafauna (Figs. $3 \& 7$ ). 


\subsection{Arctic cold seep fauna}

A large portion of the biomass at cold seeps is composed of 'background' heterotrophic fauna (also reported in Sen et al. 2018a). We did not observed the dense fields of obligate chemosymbiotic organisms and typical seep fauna (e.g. large-bodied mussels, vesicomyid bivalves, and vestimentiferan worms) that are known from other seep ecosystems mostly in lower latitude regions (e.g. Sibuet \& Olu 1998, Bergquist et al. 2005, Levin et al. 2016). Siboglinids were the only chemosymbiotic taxa, together with a few possible chemosymbiotic thyasirids (i.e. Thyasira gouldi), that we were able to collect. This is in line with previous observations of few living chemosymbiotic cold seep taxa at other high-Arctic seeps (e.g. Decker \& Olu 2012, Paull et al. 2015, Åström et al. 2017). Similarly, there have been only a few observations of chemosymbiotic fauna at Arctic hydrothermal vents along the mid-Atlantic ridge (Schander et al. 2010, Sweetman et al. 2013). Therefore, it appears that at both Arctic seeps and vents, the majority of the faunal community is composed of 'background' organisms, and true specialists (i.e. chemosymbiotic species and heterotrophic taxa specialized for chemosynthesis) are missing (Sweetman et al. 2013, Åström et al. 2017, Sen et al. 2018a).

Despite the presence of few chemosymbiotic organisms at the investigated cold seeps, we recorded 3 different morphotypes of siboglinids (Frenulata). Possibly, these are Oligobrachia (likely CPL-clade [Sen et al. 2018b], Diplobrachia sp., and Polybrachia sp.; Fig. 3). The genus Oligobrachia has been observed at all other Arctic and North Atlantic seep sites studied to date (e.g. Gebruk et al. 2003, Savvichev et al. 2018, Sen et al. 2018b) and is hypothesized to be the most widespread siboglinid among seeps on the Arctic shelf. The presence/absence of specific extant frenulate species is likely influenced by environmental characteristics such as substrate, depth, and concentrations and fluxes of sulfide/methane in the sediment (Southward et al. 1986, Dando et al. 2008, Sen et al. 2018a). The scarcity of chemosymbiotic cold seep taxa at the Arctic shelf seeps could also be limited by depth, cold bottom water temperatures, and dispersal barriers to northerly latitudes. For example, it has been suggested that a low abundance and diversity of symbiont-bearing species at shelf seeps is linked to the shallow water depth of these habitats (Schmaljohann et al. 1990, Sibuet \& Olu 1998, Sahling et al. 2003). Species that are present at shallower seeps are less likely to be seep-obligate ('seep-endemic') (Bergquist et al. 2005, Dando 2010,
Levin et al. 2016) because a shallow depth usually implies a higher input of photosynthetic organic material from surface primary production, thereby mitigating the competitive advantage of relying on chemosynthesis (Sahling et al. 2003, Tarasov et al. 2005). Moreover, it has also been proposed that high levels of competition and predation at shallow depths may largely preclude chemosynthetic fauna from these habitats (Sahling et al. 2003). Another hypothesis is linked to the dispersal by chemosymbiotic fauna to the Arctic and limitations because of consistent sub-zero bottom water temperatures, which has been suggested to have shaped deep-sea chemosymbiotic bivalve communities since the LGM and during the Holocene (Ambrose et al. 2015, Hansen et al. $2017,2019)$. This is, however, less likely at the shallower shelf seeps we studied because the bottom water temperatures are comparatively warm due to the inflow of relatively warm water to the SW Barents Sea from the NAC (Loeng 1991). Our results revealed that most of the organisms colonizing the Barents Sea cold seeps are non-chemosymbiotic, heterotrophic macrofauna forming a distinct faunal community structure, characterized by only a few taxa. The cold seeps we studied were located at comparatively shallow water depths $(<400 \mathrm{~m})$ in contrast to many other well-studied cold seep systems worldwide (Sibuet \& Olu 1998, Vanreusel et al. 2009, Levin et al. 2016). This shallow depth could possibly explain the high subset of heterotrophic 'background species' colonizing these seeps, exploiting a wide variety of habitat and food resources. Still, there is a gap in our knowledge regarding the trophic interactions among fauna inhabiting the Barents Sea seeps, and whether autochthonous chemical energy sources are utilized by a wider background benthic community remains uncertain. Here, we have provided the first insights into the interplay between different fauna and carbon sources at these shelf cold seeps, and demonstrated that at least for some selected heterotrophic taxa, $\mathrm{CBC}$ plays a significant role in their diets.

\section{SUMMARY}

We have demonstrated that highly localized methane seepage and environmental gradients at cold seeps drive strong community-level effects that override regionally constrained faunal characteristics in the Barents Sea. We reported overall high faunal abundance and biomass at the seeps despite high variability among individual samples. Chemosymbiotic siboglinid worms along with small thyasirids 
(Mendicula cf. pygmaea) were the 2 most dominant and characteristic taxa at the investigated seeps.

We documented low $\delta^{13} \mathrm{C}$ signatures in obligate chemosymbiotic siboglinids as well as in 3 species of heterotrophic polychaetes, which clearly indicates the input of $\mathrm{CBC}$ in their diets. Our results further demonstrate that other heterotrophic invertebrates at these seeps may partially incorporate CBC indirectly.

Moreover, we observed aggregations of macroand megafauna around characteristic seep features (chemosymbiotic worm tufts, microbial mats, and carbonate outcrops), suggesting that the seep habitat provides both substrate and autochthonous food resources. In this way, cold seeps in the Barents Sea function as biological hotspots where chemosynthesis provides important supplementary carbon sources to high-Arctic benthos.

Acknowledgements. This work was funded through the Centre for Arctic Gas Hydrate, Environment and Climate (CAGE) and the Research Council of Norway through its Centers' of Excellence funding scheme, \#223259. We acknowledge the captain and crew on board RV 'Helmer Hanssen' and chief scientists and scientific teams from CAGE 14_3, CAGE 15_2 and CAGE 16_5 cruises. Thanks to Woods Hole Oceanographic Institute (WHOI) and MISO, Daniel Fornari, for the collaboration developing the towed camera system during the cruise in 2015 , to the Norwegian University of Science and Technology (NTNU), AMOS/ AUR-lab, Martin Ludvigsen and the ROV team for the collaboration during 2016 and to Antje Boetius and Frank Wenzhöfer, MPI/AWI for the support with ROV blade cores. Thanks to sorters and taxonomic specialists at the biological laboratory at Akvaplan-niva, Tromsø, for processing samples and Matteus Lindgren at IG laboratory UiT. Thanks also to Thomas Kuhn who conducted the isotope analyses at the Department of Environmental Sciences at the University of Basel. We are grateful for valuable discussions on taxonomy with Graham Oliver (National Museum of Wales), Anders Warén (Swedish Museum of Natural History), Magdalena Georgieva (Natural History Museum, London), and Paul Dando (Marine Biological Association of the UK, Plymouth), and to Friederike Gründger, Wei-Li Hong, and Pavel Serov for valuable discussions and input in general. Thanks also to Paul Renaud for discussions about trophic interactions among Barents Sea fauna and to David Hammenstig for assistance with photo material in the article. The seabed images are stored at the CAGE data repository and more information is available by contacting the responsible author or data manager at CAGE (https://cage.uit.no/). J.C.'s contribution to this manuscript was funded by the Research Council of Norway (RCN \#228107). E. $\AA$ is currently post-doctoral scholar funded by VISTA - a basic research program in collaboration between The Norwegian Academy of Science and Letters and Equinor (\#6172).

\section{LITERATURE CITED}

Alfaro-Lucas JM, Shimabukuro M, Ogata IV, Fujiwara Y, Sumida PYG (2018) Trophic structure and chemosyn- thesis contributions to heterotrophic fauna inhabiting an abyssal whale carcass. Mar Ecol Prog Ser 596:1-12

Ambrose WGJ, Panieri G, Schneider A, Plaza-Faverola A and others (2015) Bivalve shell horizons in seafloor pockmarks of the last glacial-interglacial transition: a thousand years of methane emissions in the Arctic Ocean. Geochem Geophys Geosyst 16:4108-4129

Andreassen K, Hubbard A, Winsborrow M, Patton H and others (2017) Massive blow-out craters formed by hydratecontrolled methane expulsion from the Arctic seafloor. Science 356:948-953

* Åström EKL, Carroll ML, Ambrose WGJ, Carroll J (2016) Arctic cold seeps in marine methane hydrate environments: impacts on shelf macrobenthic community structure offshore Svalbard. Mar Ecol Prog Ser 552:1-18

Åström EKL, Oliver PG, Carroll ML (2017) A new genus and two new species of Thyasiridae associated with methane seeps off Svalbard, Arctic Ocean. Mar Biol Res 13:402-416

自 Åström EKL, Carroll ML, Ambrose WG, Sen A, Silyakova A, Carroll J (2018) Methane cold seeps as biological oases in the high-Arctic deep sea. Limnol Oceanogr 63:S209-S231

Bale A, Kenny A (2005) Sediment analysis and seabed characterisation. In: Eleftheriou A, McIntyre A (eds) Methods for the study of marine benthos. Blackwell Publishing, Oxford, p 43-87

Bergquist DC, Fleckenstein C, Knisel J, Begley B, MacDonald IR, Fisher CR (2005) Variations in seep mussel bed communities along physical and chemical environmental gradients. Mar Ecol Prog Ser 293:99-108

*Bicknell AWJ, Godley BJ, Sheehan EV, Votier SC, Witt MJ (2016) Camera technology for monitoring marine biodiversity and human impact. Front Ecol Environ 14:424-432

* Bohrmann G, Greinert J, Suess E, Torres M (1998) Authigenic carbonates from the Cascadia subduction zone and their relation to gas hydrate stability. Geology 26:647-650

*B Bowden DA, Rowden AA, Thurber AR, Baco AR, Levin LA, Smith CR (2013) Cold seep epifaunal communities on the Hikurangi Margin, New Zealand: composition, succession, and vulnerability to human activities. PLOS ONE 8: e76869

Braby CE, Rouse GW, Johnson SB, Jones WJ, Vrijenhoek RC (2007) Bathymetric and temporal variation among Osedax boneworms and associated megafauna on whale-falls in Monterey Bay, California. Deep Sea Res I 54:1773-1791

*Books JM, Kennicutt MC, Fisher CR, Macko SA and others (1987) Deep-sea hydrocarbon seep communities: evidence for energy and nutritional carbon sources. Science 238:1138-1142

Carney RS (1994) Consideration of the oasis analogy for chemosynthetic communities at Gulf of Mexico hydrocarbon vents. Geo-Mar Lett 14:149-159

* Carroll ML, Denisenko SG, Renaud PE, Ambrose WGJ (2008) Benthic infauna of the seasonally ice-covered western Barents Sea: patterns and relationships to environmental forcing. Deep Sea Res II 55:2340-2351

Clarke KR, Gorley RN (2006) PRIMER V6: user manual/tutorial. PRIMER-E, Plymouth

* Cochrane SKJ, Pearson TH, Greenacre M, Costelloe J, Ellingsen IH, Dahle S, Gulliksen B (2012) Benthic fauna and functional traits along a Polar Front transect in the Barents Sea - advancing tools for ecosystem-scale assessments. J Mar Syst 94:204-217

Dando PR (2010) Biological communities at marine shallowwater vent and seep sites. In: Kiel S (ed) The vent and seep biota. Springer, Dordrecht, p 333-378

Dando PR, Spiro B (1993) Varying nutritional dependence of the thyasirid bivalves Thyasira sarsi and T. equalis on 
chemoautotrophic symbiotic bacteria, demonstrated by isotope ratios of tissue carbon and shell carbonate. Mar Ecol Prog Ser 92:151-158

Dando PR, Southward AJ, Southward EC, Lamont P, Harvey $\mathrm{R}$ (2008) Interactions between sediment chemistry and frenulate pogonophores (Annelida) in the north-east Atlantic. Deep Sea Res I 55:966-996

* Decker C, Olu K (2012) Habitat heterogeneity influences cold-seep macrofaunal communities within and among seeps along the Norwegian margin - Part 2: Contribution of chemosynthesis and nutritional patterns. Mar Ecol 33:231-245

* Decker C, Morineaux M, Van Gaever S, Caprais JCC and others (2012) Habitat heterogeneity influences cold-seep macrofaunal communities within and among seeps along the Norwegian margin. Part 1: Macrofaunal community structure. Mar Ecol 33:205-230

* Dubilier N, Bergin C, Lott C (2008) Symbiotic diversity in marine animals: the art of harnessing chemosynthesis. Nat Rev Microbiol 6:725-740

Dufour SC (2005) Gill anatomy and the evolution of symbiosis in the bivalve family Thyasiridae. Biol Bull (Woods Hole) 208:200-212

Fauchald K, Jumars PA (1979) The diet of worms: a study of polychaete feeding guilds. Oceanogr Mar Biol Annu Rev 17:193-284

Ferrier-Pagès C, Leal MC (2018) Stable isotopes as tracers of trophic interactions in marine mutualistic symbioses. Ecol Evol 9:723-740

Freytag JK, Girguis PR, Bergquist DC, Andras JP, Childress JJ, Fisher CR (2001) A paradox resolved: Sulfide acquisition by roots of seep tubeworms sustains net chemoautotrophy. Proc Natl Acad Sci USA 98:13408-13413

Gage JD, Tyler PA (1991) Deep-sea biology: a natural history of organisms at the deep-sea floor. Part I. Cambridge University Press, Cambridge

Gebruk AV, Krylova EM, Lein AY, Vinogradov GM and others (2003) Methane seep community of the Håkon Mosby mud volcano (the Norwegian Sea): composition and trophic aspects. Sarsia 88:394-403

Graf G (1989) Benthic-pelagic coupling in a deep-sea benthic community. Nature 341:437-439

Guillon E, Menot L, Decker C, Krylova E, Olu K (2017) The vesicomyid bivalve habitat at cold seeps supports heterogeneous and dynamic macrofaunal assemblages. Deep Sea Res I 120:1-13

*Hansen J, Hoff U, Sztybor K, Rasmussen TL (2017) Taxonomy and palaeoecology of two late Pleistocene species of vesicomyid bivalves from cold methane seeps at Svalbard $\left(79^{\circ} \mathrm{N}\right)$. J Molluscan Stud 83:270-279

*Hansen J, Ezat MM, Åström EKL, Rasmussen TL (2019) New late Pleistocene species of Acharax from Arctic methane seeps off Svalbard. J Syst Palaeontology, doi:10.1080/ 14772019.2019.1594420

Hobson KA, Welch HE (1992) Determination of trophic relationships within a high Arctic marine food web using $\delta^{13} \mathrm{C}$ and $\delta^{15} \mathrm{~N}$ analysis. Mar Ecol Prog Ser 84:9-18

*Hobson KA, Ambrose WG Jr, Renaud PE (1995) Sources of primary production, benthic-pelagic coupling, and trophic relationships within the Northeast Water Polynya: insights from $\delta^{13} \mathrm{C}$ and $\delta^{15} \mathrm{~N}$ analysis. Mar Ecol Prog Ser 128:1-10

Holding JM, Duarte CM, Delgado-Huertas A, Soetaert K and others (2017) Autochthonous and allochthonous contributions of organic carbon to microbial food webs in Svalbard fjords. Limnol Oceanogr 62:1307-1323

Holler $T$, Wegener G, Knittel $K$, Boetius A, Brunner B, Kuypers MMM, Widdel F (2009) Substantial ${ }^{13} \mathrm{C} /{ }^{12} \mathrm{C}$ and
D/H fractionation during anaerobic oxidation of methane by marine consortia enriched in vitro. Environ Microbiol Rep 1:370-376

*Holm-Hansen O, Lorenzon C, Holmes R, Strickland J (1965) Fluorometric determination of chlorophyll. ICES J Mar Sci 30:3-15

* Hong WL, Torres ME, Carroll J, Crémière A, Panieri G, Yao $\mathrm{H}$, Serov P (2017) Seepage from an Arctic shallow marine gas hydrate reservoir is insensitive to momentary ocean warming. Nat Commun 8:15745

*House CH, Schopf JW, Stetter KO (2003) Carbon isotopic fractionation by Archaeans and other thermophilic prokaryotes. Org Geochem 34:345-356

*Hügler M, Sievert SM (2011) Beyond the Calvin Cycle: autotrophic carbon fixation in the ocean. Annu Rev Mar Sci 3: 261-289

Hurlbert SH (1971) The nonconcept of species diversity: a critique and alternative parameters. Ecology 52: 577-586

Jakobsson M, Mayer L, Coakley B, Dowdeswell JA and others (2012) The international bathymetric chart of the Arctic Ocean (IBCAO) version 3.0. Geophys Res Lett 39: L12609

Jensen P, Aagaard I, Burke RA Jr, Dando PR and others (1992) 'Bubbling reefs' in the Kattegat: submarine landscapes of carbonate-cemented rocks support a diverse ecosystem at methane seeps. Mar Ecol Prog Ser 83:103-112

Jørgensen LL, Renaud PE, Cochrane SKJ, Lindal L, Renaud PE, Cochrane SKJ (2011) Improving benthic monitoring by combining trawl and grab surveys. Mar Pollut Bull 62: 1183-1190

Knittel K, Boetius A (2009) Anaerobic oxidation of methane: progress with an unknown process. Annu Rev Microbiol 63:311-334

Levin LA (2005) Ecology of cold seep sediments: interactions of fauna with flow, chemistry and microbes. Oceanogr Mar Biol Annu Rev 43:1-46

* Levin LA, Baco AR, Bowden D, Colaço A and others (2016) Hydrothermal vents and methane seeps: rethinking the sphere of influence. Front Mar Sci 3:72

* Loeng H (1991) Features of the physical oceanographic conditions of the Barents Sea. Polar Res 10:5-18

K Lösekann T, Robador A, Niemann H, Knittel K, Boetius A, Dubilier N (2008) Endosymbioses between bacteria and deep-sea siboglinid tubeworms from an Arctic cold seep (Haakon Mosby Mud Volcano, Barents Sea). Environ Microbiol 10:3237-3254

Martens CS, Chanton JP, Paull CK (1991) Biogenic methane from abyssal brine seeps at the base of the Florida escarpment. Geology 19:851-854

Meyer KS, Soltwedel T, Bergmann M (2014) High biodiversity on a deep-water reef in the eastern Fram Strait. PLOS ONE 9:e105424

Niemann H, Linke P, Knittel K, MacPherson E and others (2013) Methane-carbon flow into the benthic food web at cold seeps - a case study from the Costa Rica subduction zone. PLOS ONE 8:e74894

Oksanen J, Blanchet F, Kindt R, Legendre P, O'Hara R (2016) vegan: community ecology package. $\mathrm{R}$ Package version 2.3-3. https://CRAN.R-project.org/package=vegan

Oliver PG, Killeen IJ (2002) The Thyasiridae (Mollusca: Bivalvia) of the British continental shelf and North Sea oil fields: an identification manual. National Museums \& Galleries of Wales, Cardiff

*Patton H, Hubbard A, Andreassen K, Auriac A and others (2017) Deglaciation of the Eurasian ice sheet complex. Quat Sci Rev 169:148-172 
Paull CK, Dallimore SR, Caress DW, Gwiazda R and others (2015) Active mud volcanoes on the continental slope of the Canadian Beaufort Sea. Geochem Geophys Geosyst 16:3160-3181

Plaza-Faverola A, Keiding M (2019) Correlation between tectonic stress regimes and methane seepage on the western Svalbard margin. Solid Earth 10:79-94

Portnov A, Vadakkepuliyambatta S, Mienert J, Hubbard A (2016) Ice-sheet-driven methane storage and release in the Arctic. Nat Commun 7:10314

Rasmussen TL, Thomsen E, lubowska MA, Jessen S, Solheim A, Koç N (2007) Paleoceanographic evolution of the SW Svalbard margin $\left(76^{\circ} \mathrm{N}\right)$ since $20000{ }^{14} \mathrm{C}$ yr BP. Quat Res 67:100-114

Reeburgh WS (2007) Oceanic methane biogeochemistry. Chem Rev 107:486-513

Renaud PE, Morata N, Carroll ML, Denisenko SG, Reigstad M (2008) Pelagic-benthic coupling in the western Barents Sea: processes and time scales. Deep Sea Res II 55: $2372-2380$

Robinson JJ, Cavanaugh CM (1995) Expression of form I and form II Rubisco in chemoautotrophic symbioses: implications for the interpretation of stable carbon isotope values. Limnol Oceanogr 40:1496-1502

Rodrigues CF, Hilário A, Cunha MR, Weightman AJ, Webster G (2011) Microbial diversity in Frenulata (Siboglinidae, Polychaeta) species from mud volcanoes in the Gulf of Cadiz (NE Atlantic). Antonie van Leeuwenhoek 100: 83-98

Sahling H, Galkin SV, Salyuk A, Greinert J, Foerstel H, Piepenburg D, Suess E (2003) Depth-related structure and ecological significance of cold-seep communities a case study from the Sea of Okhotsk. Deep Sea Res I 50: 1391-1409

Sahling H, Römer M, Pape T, Bergès B and others (2014) Gas emissions at the continental margin west of Svalbard: mapping, sampling, and quantification. Biogeosciences 11:6029-6046

Savvichev AS, Kadnikov VV, Kravchishina MD, Galkin SV and others (2018) Methane as an organic matter source and the trophic basis of a Laptev Sea cold seep microbial community. Geomicrobiol J 35:411-423

Schander C, Rapp HT, Kongsrud JA, Bakken T and others (2010) The fauna of hydrothermal vents on the Mohn Ridge (North Atlantic). Mar Biol Res 6:155-171

Schmaljohann R, Faber E, Whiticar MJ, Dando PR (1990) Co-existence of methane- and sulphur-based endosymbioses between bacteria and invertebrates at a site in the Skagerrak. Mar Ecol Prog Ser 61:119-124

Sen A, Åström EKL, Hong WL, Portnov A and others (2018a) Geophysical and geochemical controls on the megafaunal community of a high Arctic cold seep. Biogeosciences 15:4533-4559

Sen A, Duperron S, Hourdez S, Piquet B and others (2018b) Cryptic frenulates are the dominant chemosymbiotrophic fauna at Arctic and high latitude Atlantic cold seeps. PLOS ONE 13:e0209273

Sen A, Himmler T, Hong WL, Chitkara C and others (2019) Atypical biological features of a new cold seep site on the Lofoten-Vesterålen continental margin (northern Norway). Sci Rep 9:1762

Serov P, Vadakkepuliyambatta S, Mienert J, Patton H and others (2017) Postglacial response of Arctic Ocean gas hydrates to climatic amelioration. Proc Natl Acad Sci USA 114:6215-6220

Sibuet M, Olu K (1998) Biogeography, biodiversity and fluid dependence of deep-sea cold-seep communities at active and passive margins. Deep Sea Res II 45:517-567

Solheim A, Elverhøi A (1993) Gas-related sea floor craters in the Barents Sea. Geo-Mar Lett 13:235-243

Søreide JE, Hop H, Carroll ML, Falk-Petersen S, Hegseth EN (2006) Seasonal food web structures and sympagicpelagic coupling in the European Arctic revealed by stable isotopes and a two-source food web model. Prog Oceanogr 71:59-87

* Søreide JE, Falk-Petersen S, Hegseth EN, Hop H, Carroll ML, Hobson KA, Blachowiak-Samolyk K (2008) Seasonal feeding strategies of Calanus in the high-Arctic Svalbard region. Deep Sea Res II 55:2225-2244

Southward AJ, Southward EC, Dando PR, Barrett RL, Ling R (1986) Chemoautotrophic function of bacterial symbionts in small pogonophora. J Mar Biol Assoc UK 66:415

* Sweetman A, Levin L, Rapp H, Schander C (2013) Faunal trophic structure at hydrothermal vents on the southern Mohn's Ridge, Arctic Ocean. Mar Ecol Prog Ser 473: $115-131$

* Sweetman AK, Smith CR, Shulse CN, Maillot B and others (2019) Key role of bacteria in the short-term cycling of carbon at the abyssal seafloor in a low particulate organic carbon flux region of the eastern Pacific Ocean. Limnol Oceanogr 64:694-713

Syvertsen EE (1991) Ice algae in the Barents Sea: types of assemblages, origin, fate and role in the ice-edge phytoplankton bloom. Polar Res 10:277-288

Tarasov VG, Gebruk AV, Mironov AN, Moskalev LI (2005) Deep-sea and shallow-water hydrothermal vent communities: Two different phenomena? Chem Geol 224:5-39

Taylor JD, Glover EA (2010) Chemosymbiotic bivalves. In: Kiel S (ed) The vent and seep biota. Springer, Dordrecht, p 107-135

* Thiel V, Hügler M, Blümel M, Baumann HI and others (2012) Widespread occurrence of two carbon fixation pathways in tubeworm endosymbionts: lessons from hydrothermal vent associated tubeworms from the Mediterranean Sea. Front Microbiol 3:423

*Vander Zanden MJ, Shuter BJ, Lester N, Rasmussen JB (1999) Patterns of food chain length in lakes: a stable isotope study. Am Nat 154:406-416

Van Dover CL, Fry B (1989) Stable isotopic compositions of hydrothermal vent organisms. Mar Biol 102:257-263

Vanreusel A, Andersen A, Boetius A, Connelly D and others (2009) Biodiversity of cold seep ecosystems along the European margins. Oceanography (Wash DC) 22:110-127

*Vismann B (1991) Sulfide tolerance: physiological mechanisms and ecological implications. Ophelia 34:1-27

WWassmann P, Reigstad M, Haug T, Rudels B and others (2006) Food webs and carbon flux in the Barents Sea. Prog Oceanogr 71:232-287

Zaborska A, Carroll J, Papucci C, Torricelli L, Carroll ML, Walkusz-Miotk J, Pempkowiak J (2008) Recent sediment accumulation rates for the western margin of the Barents Sea. Deep Sea Res II 55:2352-2360

* Zapata-Hernández G, Sellanes J, Thurber AR, Levin LA, Chazalon F, Linke P (2014) New insights on the trophic ecology of bathyal communities from the methane seep area off Concepción, Chile ( $\left.36^{\circ} \mathrm{S}\right)$. Mar Ecol 35:1-21

Submitted: March 25, 2019; Accepted: August 9, 2019

Proofs received from author(s): October 19, 2019
Editorial responsibility: James McClintock Birmingham, Alabama, USA 